This item was submitted to Loughborough's Research Repository by the author.

Items in Figshare are protected by copyright, with all rights reserved, unless otherwise indicated.

\title{
Regional-scale drivers of groundwater faunal distributions
}

PLEASE CITE THE PUBLISHED VERSION

http://dx.doi.org/10.1086/678460

\section{PUBLISHER}

University of Chicago Press / @ Society for Freshwater Science

\section{VERSION}

AM (Accepted Manuscript)

\section{PUBLISHER STATEMENT}

This work is made available according to the conditions of the Creative Commons Attribution-NonCommercialNoDerivatives 4.0 International (CC BY-NC-ND 4.0) licence. Full details of this licence are available at: https://creativecommons.org/licenses/by-nc-nd/4.0/

\section{LICENCE}

CC BY-NC-ND 4.0

\section{REPOSITORY RECORD}

Johns, Tim, J. Iwan Jones, Lee Knight, Louise Maurice, Paul J. Wood, and Anne L. Robertson. 2019. "Regional-scale Drivers of Groundwater Faunal Distributions". figshare. https://hdl.handle.net/2134/18380. 
1 Running head: Groundwater faunal distributions

2

3 REGIONAL SCALE DRIVERS OF GROUNDWATER FAUNAL DISTRIBUTIONS

4

5 Tim Johns ${ }^{1,6}$, J. Iwan Jones $^{2}$, Lee Knight ${ }^{3}$, Louise Maurice ${ }^{4}$, Paul Wood $^{5}$, Anne

6 Robertson $^{6 *}$

7 1. Environment Agency, Red Kite House, Howbery Park, Wallingford, Oxfordshire,

8 OX10 8BD, UK.

9 2. School of Biological and Chemical Sciences, Queen Mary University of London, 10 London E14NS

11 3. No. 1 The Linhay, North Kenwood Farm, Oxton, Nr Kenton, Devon, EX6 8EX

12 4. British Geological Survey, Maclean Building, Crowmarsh Gifford, Wallingford, 13 Oxfordshire, OX10 8BB UK.

14 5. Centre for Hydrological and Ecosystems Science, Department of Geography,

15 Loughborough University, Loughborough, Leicestershire, LE11 3TU, UK 6* Department of Life Sciences, University of Roehampton, Holybourne Avenue, London SW15 4JD, UK. T: +44 (0) 2083923456 E: a.robertson@roehampton.ac.uk *Author to whom correspondence should be addressed 
Freshwater aquifers are a major source of drinking water; they also possess unique assemblages of organisms. However, little is known about the distributional drivers of obligate groundwater organisms at the regional scale. We examine the distribution and composition of stygobiont assemblages in a complex geological setting and explore the relationship between groundwater fauna, hydrogeology and water chemistry. In the study area we grouped similar geologies into five hydrogeological formations (hydro-units) within which habitats for groundwater fauna were broadly similar. We found that the occurrence of stygobionts differed significantly between hydro-units. Stygobionts were significantly less likely to be recorded in mudstone/siltstone and sandstone aquifers compared with carbonate rocks or with igneous/metamorphic rocks. Variance partitioning indicated that the hydro-units explained a greater proportion of the variance $(7.52 \%)$ in the groundwater community than water chemistry (5.02\%). However, much of the variation remained unexplained. The macrofaunal stygobiont species in our study area formed three groups: (1) Niphargus glenniei was recorded in a range of hydrounits but only in the west of the study area. (2) Niphargus kochianus, Niphargus fontanus, Proasellus cavaticus and Crangonyx subterraneus were predominately recorded in carbonate aquifers in the east of the study area. (3) Niphargus aquilex and Microniphargus leruthi, were found throughout the study area and in a range of hydro-units. We hypothesise that physical barriers exist that prevent some stygobiont taxa from colonizing apparently suitable geologies; the low permeability deposits dividing the western and eastern parts of the study area may partly explain the observed distributions. 
KEYWORDS

52 Hydrogeology, Geology, British Isles, Devon, Dorset, Stygobionts, Stygophiles, Niphargus, Water chemistry, groundwater. 
Freshwater aquifers represent approximately $65 \%$ of drinking water sources in the

EU (Scheidleder and Visser, 2012), and thus their hydrogeology and chemistry are generally well known. In addition to their value as a resource, groundwaters possess unique assemblages of organisms and globally harbour a large reservoir of biodiversity with a high proportion of endemic and rare species compared with surface water habitats (Sket 2004, Gibert et al. 2009). In response to the energy poor nature of subterranean environments, groundwater invertebrates typically have low population densities and extended life histories with delayed maturity, greater longevity, smaller egg-clutch size, larger eggs and lower percentages of mature ovigerous females than related surface-dwelling (epigean) species (Gibert et al. may result in an increased vulnerability to anthropogenic impacts compared to epigean taxa. This vulnerability may be compounded by their slow dispersal rates (Culver et al. 2009).

Although research centred on surface-groundwater interactions is burgeoning and has moved from descriptive studies to a more experimental approach (introduction to this special issue, Larned 2012), research into deeper groundwaters is less developed, perhaps because of the difficulties in accessing this environment. Despite numerous studies describing the occurrence and distribution of groundwater fauna (e.g. Botosaneanu 1986, Proudlove et al. 2003, Robertson et al 2009, Gibert et al. 2009), relatively little is known about the environmental and/or historical drivers of their distribution patterns. The relative importance of a given driver is likely to vary across spatial and temporal scales. At the continental scale, stygobiont distribution 
patterns have been shaped by events in deep geological time, for example the movement of continental plates (e.g. Schminke 1974), orogenic and eustatic events (Stock 1980, Boutin and Coineau 1990, Notenboom 1991), and the alternation of marine transgressions and regressions (e.g. Jaume and Humphreys 2001). Long term climate change has also shaped the distribution of groundwater taxa. In the northern hemisphere the Pleistocene glaciations appear to have had a catastrophic effect on groundwater communities, leaving Northern Europe with a depauperate groundwater fauna compared to the rest of Europe. For example, only eight species of obligate groundwater macro Crustacea have been recorded from mainland Britain, including four species of Niphargus, the most speciose groundwater genus (Proudlove et al. 2003, Robertson et al. 2009, Knight and Gledhill 2010). This contrasts with 134 species of Niphargus recorded in the Balkans biogeographical area (McInerney et al. 2014). In Northern Europe, contemporary distributions reflect patterns of past glacial activity (e.g. Strayer 1994, Robertson et al. 2009). However, there are some species present in formerly deglaciated areas, and those species that remain in Northern Europe must have survived the impacts of glacial and periglacial conditions (Holsinger 1988, Proudlove et al. 2003, Kristjansson and Svavarsson 2007, Lefebure et al. 2007, Mclnerney et al. 2014). Indeed, recent research has shown that the small number of Niphargus species that are present in the UK are ancient endemics that have survived millions of years of extreme climate changes (Mclnerney et al. 2014). At smaller scales, stygobiont distribution patterns are influenced by the availability of suitable habitat and aquifer connectivity as well as the ecological tolerances, competitive interactions and dispersal abilities of species (Gibert et al. 1994, Castellarini et al. 2007, Hahn and Fuchs 2009). 
104 Regional investigations that have gathered large datasets on stygobiont presence and environmental conditions are relatively rare (Mauclaire and Gibert 2001, Galassi et al. 2009, Martin et al. 2009, Dole-Olivier et al. 2009b, Hahn and Fuchs 2009). In these studies, geology appears to be an important determinant of stygobiont distributions because it controls the availability of suitable habitats (Datry et al. 2005, Dole-Olivier et al. 2009b, Botosaneanu 1986, Hahn and Fuchs 2009). Most stygobionts are dependent on well-developed void spaces with wide pore throats or fracture apertures. These features commonly occur in karstic, porous and fractured aquifers and this is where obligate groundwater communities are most diverse and abundant (e.g. Gibert and Deharveng 2002, Dole-Olivier et al. 2009b). In addition to providing physical habitat, the degree to which void spaces are developed and connected also influences the exchange of oxygen, nutrients and organic matter with the surface, and thus the availability of food for the groundwater community.

Observed distribution patterns may also relate to the opportunities for dispersal. In groundwaters the habitat is very fragmented, limiting the dispersal of groundwater fauna (Lefebure et al. 2007). Stygobiont assemblages are therefore characterised by endemic species with limited geographical ranges. Even species which are apparently widely distributed have emerged as cryptic lineages (Lefebure et al. 2007, Trontelj et al. 2009, Mclnerney et al. 2014). Habitat fragmentation in groundwaters has been most frequently discussed in relation to karst habitats (Trontelj et al. 2009, Modovan et al. 2012), however it may also occur as a result of the juxtaposition of different geologies. The presence of mudstones with low permeability and restricted void spaces may form a physical barrier to stygobiont dispersal (Hahn and Fuchs 2009). Some stygobiont taxa, however, may be able to exploit superficial deposits or the hyporheic zones of rivers as a means of dispersal (e.g. Ward and Palmer 1994, 
129 Castellarini et al. 2007). The water chemistry of an aquifer, e.g. concentrations of dissolved organic carbon and nitrates, may also correlate with the distribution of groundwater taxa (Martin et al. 2009).

In this study we address the limited understanding of the drivers of groundwater faunal distributions at the regional scale by carrying out an extensive sampling programme within the complex geological setting of the south-west of the UK. Our aims were to determine the detailed spatial distributions of the UK stygobiont species in the study area and investigate whether the distribution and composition of stygobiont assemblages varies with hydrogeology and water chemistry. We build on the design of the PASCALIS project on European groundwater biodiversity which adopted a hierarchical sampling strategy and included two types of aquifer (porous and karstic) (Dole-Olivier et al. 2009a). Our approach was to group the different hydrogeological formations present in the study area into five 'hydro-units' where the different geologies within a given hydro-unit provide broadly similar habitats for groundwater fauna. We sampled groundwater assemblages within the different hydro-units to determine whether species were restricted to particular hydro-units, and sampled water chemistry to determine whether faunal distributions reflect local variation in water chemistry.

\section{METHODS}

\section{Study area and hydrogeological units}

151 The study area in south west England is an area of contrasting topography and geology dominated by lowland (max. elevation $279 \mathrm{~m}$ ) sedimentary rocks in the east and higher elevation (max. $621 \mathrm{~m}$ ) metamorphic and igneous rocks in the west (Fig. 
1). The region's annual average rainfall is approximately $900-1000 \mathrm{~mm}$ (http://www.metoffice.gov.uk/climate/uk/sw/).

Within the study area 271 different geological formations have been mapped at the 1:50,000 scale (Reproduced from the British Geological Survey Map data at the original scale of 1:50 000 Licence 2011/057 British Geological Survey. @NERC. All rights reserved). To assess the general hydrogeological controls on species distributions, these geologies were grouped into categories termed "hydro-units". The hydro-units are based on broad differences in geology and groundwater flow characteristics which result in different groundwater habitats for fauna. There are two main types of groundwater flow: intergranular and flow through fractures (Price 1996). Unconsolidated granular deposits in which all groundwater movement is intergranular were grouped together as hydro-unit 1 because these deposits form a habitat in which fauna can only live within the pore spaces between the sediment (hydro-unit 2) because there were insufficient data to determine differences in habitat type between them. They were grouped separately from other strata because groundwater flow is only through fractures, and due to of their volcanic origin, they have a bedrock geochemistry that is different to other consolidated rocks. Sedimentary rocks may be non-carbonate or carbonate. Non-carbonate sedimentary rocks often have varying degrees of consolidation and, therefore, form aquifers in which flow may be both inter-granular in the less consolidated areas and through fractures in consolidated rock. They are classified according to grain size as mudstones, siltstones and sandstones (Price 1996). Sandstones form aquifers with 
much higher permeability than siltstones and mudstones which often form aquitards or aquicludes (Price 1996, Allen et al. 1997). The difference in permeability is likely to result in both a different groundwater chemistry and a different physical habitat for fauna. They were therefore separated into a mudstone/siltstone hydro-unit (3) and a sandstone hydro-unit (4). Hydro-unit 5 includes all carbonate geologies. In these rocks, fractures are enlarged by dissolution to form fissures and caves providing substantially larger and more inter-connected void spaces than any other rock type, which can serve as habitats for fauna. In the study area carbonate rocks range from the weakly karstified Cretaceous Chalk (Maurice et al, 2006) to the highly karstified limestones of Devonian and Carboniferous. Where the Chalk overlies the Upper Greensand Formation these strata are commonly in hydraulic continuity (Allen et al. 1997). This means that it is likely that fauna may be living in both the Chalk and the Upper Greensand, and that it is not possible to distinguish the two habitats. The Upper Greensand Formation is a non-karstic aquifer comprising sandstones and sands, but where it is in hydraulic continuity with the Chalk it was included in the carbonate hydro-unit (5). Elsewhere, outcrops of the Upper Greensand Formation are isolated from the Chalk and, were therefore grouped with the other sandstones in the sandstone hydro-unit (4). The properties of the five hydro-units are summarized in Table 1.

The distribution and extent of the different hydro-units varied across the study area (Fig. 1). In particular there was a pronounced difference between the hydro-units in the east and west of the study area. Mudstones/siltstones (hydro-unit 3), covered the largest surface area in the study region and were most common in the west. Sandstones (hydro-unit 4), were the next most common, and occurred across the 
region, with the largest outcrops in the west and north-west. Carbonate aquifers (hydro-unit 5), were predominately located in the east, where there were extensive Cretaceous chalk downlands. In the west carbonate rocks were limited to much smaller isolated outcrops of older limestones, separated by mudstones and sandstones. Granular material (hydro-unit 1) was restricted to the far south eastern were only present in the west and south west.

\section{Sampling}

In total, 221 sites were sampled. The number of samples taken within each hydrounit was approximately proportionate to the surface area it occupied (Table 1). Within each unit, sites were selected to maximize spatial coverage. Boreholes free from fine mesh well screens and in-situ equipment were preferentially selected. Borehole and well sampling sites ranged from 0.36 to $130 \mathrm{~m}$ deep and 0.05 to $2 \mathrm{~m}$ in diameter. Where there were insufficient boreholes or wells, springs were sampled. Each site was sampled on a single occasion. Most samples (197) were collected between September 2009 and May 2010, and water chemistry measurements were made at water chemistry data were obtained for these samples.

Fauna were collected from boreholes and wells using a weighted plankton net $(63 \mu \mathrm{m}$ mesh, diameter varied from $35-300 \mathrm{~mm}$ dependent on borehole aperture). The net was lowered to the base of the borehole/well and moved up and down vigorously to

227 disturb the sediment before retrieval. For springs, a net was swept through the sediment of the spring chamber or at the spring head source. The samples were 
preserved in $>90 \%$ ethanol and all equipment thoroughly cleaned between sites. In the laboratory animals were separated from debris, stygobionts were identified to species level using Gledhill et al. (1993) and Knight and Gledhill (2010); Ostracoda (identified to class), Hydracarina (identified to clade) and Copepoda and Oligochaeta (identified to sub-class) were probably predominantly stygophiles and stygoxenes. Freshwater epigean taxa and terrestrial taxa were noted.

Electrical conductivity, $\mathrm{pH}$, dissolved oxygen and temperature were recorded using a multi-parameter probe (YSI 600QS) lowered to the base of each borehole/well. The probe was calibrated prior to each sampling trip. Water samples for laboratory analysis were taken using a bailer. At springs, field chemistry and water samples were taken directly from the spring head or catchpit. Water samples were filtered and refrigerated before dispatch to analytical laboratories within 48 hours. Analysis for major anions $\left(\mathrm{Cl}^{-}, \mathrm{SO}_{4}{ }^{2-}, \mathrm{NO}_{3}{ }^{-}\right)$and cations $\left(\mathrm{Mg}^{2+}, \mathrm{K}^{+}, \mathrm{Na}^{+}, \mathrm{Ca}^{2+}\right)$ was performed using high pressure liquid chromatography using a Dionex ED40 electrochemical segmented flow analyser (min. reporting value $0.2 \mathrm{mgl}^{-1}$ ).

Data analysis

Chemical data were tested for normality (Q-Q plots) and homogeneity of variance (Fligner- Killeen test), and a non-parametric ANOVA was used to investigate differences in water chemistry between the five different hydro-units (selected as factors). A generalized linear model with a binomial error structure was then used to examine the relationships between presence/absence of stygobiont taxa, hydro-units 
and water chemistry. Statistical analyses were performed using R version 3.0.2 (2013), using standard packages plus the package for analysis of over dispersed data (Lesnoff et al, 2012). The initial model selected hydro-unit as a factor. The model was then run with all stygobiont presence/absence data, using the carbonate hydro-unit (5) as the point of comparison because it: i) comprised the most sites, ii) was the strata in which stygobionts were most common, and iii) also yielded a broad range of water quality data. Models were then run for each set of water quality data (i.e. each chemical determinand with associated presence/absence and hydro-unit data), the odds ratios were calculated and predicted probabilities of stygobiont presence were determined from the mean value for each determinand. Different permutations of the model were run to explore whether the inclusion of sample type (borehole, well or spring) and/or water quality data improved the model, and to identify any interactions between factors. Outputs were checked to verify the data were not over dispersed and models were then compared, using a one-way ANOVA, describe the relative likelihood of recording stygobionts in each hydro-unit.

The association between the faunal community and environmental variables was investigated using Canonical Correspondence Analysis (CCA) within Canoco for Windows Ver.4.51 (Ter Braak and Smilauer 1998). Only those sites with concurrent chemistry analysis (190 samples) were used in this analysis and sites where there was uncertainty over the geological unit from which the sample was obtained ( 7 samples) were excluded. 
278 A series of ordinations were undertaken including groundwater faunal abundance, hydro-units and water chemistry data. Both stygobiont and stygophile taxa were included in the analysis to reflect the diversity and distribution of the community recorded from each sample location where fauna were recorded, although the results and discussion are focused on the stygobiont taxa. To determine how individual variables might explain patterns in the faunal data (stygobionts and stygophiles), we applied the forward selection procedure ( $\mathrm{P} \leq 0.05$ after Bonferonni correction). Only those variables having a significant association with the faunal community distribution were included in the final analysis and presented in the output diagrams. The stygobiont Antrobathynella stammeri (Jakobi, 1954), which was recorded only once, was fitted passively to the ordination. To determine the proportion of variance in the faunal data explained by the hydro-units and water chemistry data, a variance partitioning approached was used (Borcard 1992). This constrained the species ordination for each of these co-variable groups in turn, while partialling out the other variables from the ordination.

As expected water chemistry varied significantly between the five hydro-units, reflecting differences in bedrock geochemistry and permeability. With the exception of potassium, significant differences were recorded between each chemical determinand and the five hydro-units (Table 2).

Stygobionts and/or stygophiles were recorded from $70 \%$ of the study sites (Table 3 ) and all hydro-units (Fig.1). The remaining $30 \%$ of sites contained no groundwater 
taxa although epigean taxa were recorded at some sites. Stygophiles were more abundant and recorded more frequently than stygobionts (59\% compared to $34 \%$ of sites). All of the stygobiont macro-Crustacea known to occur in the UK were recorded, although their presence and community composition varied considerably across the study region. Boreholes in the carbonate hydro-unit (unit 5) supported the most diverse stygobiont communities, with up to four taxa recorded in a single borehole, compared to a maximum of two taxa from other hydro-units (Fig. 2).

Niphargus aquilex (Schiödte, 1855), was recorded throughout the study region and from all hydro-units (Fig. 2). In contrast, Niphargus glenniei (Spooner, 1952) was only recorded in the west of the study area despite being recorded in most hydrounits. Niphargus kochianus (Bate, 1859), Niphargus fontanus (Bate, 1859) and Proasellus cavaticus (Leydig, 1871) were primarily recorded in the carbonate hydrounit (5) in the east of the region (Fig. 2), but were absent from this hydro-unit and all other hydro-units in the west of the study area. Crangonyx subterraneus (Bate, 1859) and Microniphargus leruthi (Schellenberg 1934) were rare, and were primarily recorded in the east (Fig. 2). Antrobathynella stammeri (Jakobi, 1954) was recorded once.

The occurrence of stygobionts differed significantly between hydro-units $\left[\chi^{2}=33.8\right.$, $d f=5, p<0.001$, Table 4]. From the odds ratio (OR), stygobionts were $88 \%$ less likely to be recorded in mudstone/siltstones (hydro-unit 3) [OR=0.12, $97.5 \% \mathrm{Cl} 0.034-$ $0.030, p<0.001$ ] than in carbonates (hydro-unit 5 ) and about $80 \%$ less likely to be recorded in sandstones (hydro-unit 4) [OR=0.20,97.5\% Cl 0.08-0.50, $p<0.001]$, than carbonates (hydro-unit 5). Stygobionts were also less likely to be recorded in 
mudstones/siltstones (hydro-unit 3) and sandstones (hydro-unit 4) than in igneous/metamorphic sites (hydro-unit 2) and granular sites (hydro-unit 1). All differences were significant except for sandstone sites relative to granular sites. The generalized linear model generally improved (based on the AIC scores and level of significance) with the addition of either sample type or a water chemistry determinand as a value. Mudstones/siltstones and sandstones (hydro-units 3 and 4) were significantly different from carbonate rocks (hydro-unit 5) throughout the iterations. No significant interactions between factors (e.g. hydro-unit combined with sample type) were identified. By including water chemistry determinands with presence/absence in the model, improved models were obtained with calcium, chloride and $\mathrm{pH}$, indicating a potential association of these variables with stygobiont presence. The predicted probability of stygobiont presence in any hydro-unit was higher with increasing calcium concentrations. In contrast, the predicted probability of stygobiont presence in any hydro-unit declined as chloride concentrations increased. There was no clear relationship between $\mathrm{pH}$ and the presence of stygobionts.

The inclusion of sample type significantly improved the models that included electrical conductivity, magnesium, potassium, sodium, sulphate and dissolved organic carbon. For the model with potassium, the igneous/metamorphic aquifers (hydro-unit 2) were identified as significantly different when sample type was included. The odds ratio of recording stygobionts in this unit was also lower compared with the simplest model where no additional factors were included. Overall there was a greater likelihood of recording stygobionts in springs (sample type 3) than boreholes (sample type 1: Table 4). However, presence or absence of 
stygobionts across the hydro-units was significant $(p<0.001)$ irrespective of the inclusion of sample type in the model.

Canonical correspondence analysis indicated a separation of the sample centroids for the five hydro-units based on the faunal community data (Fig. 3), the first two canonical axes explained $20.0 \%$ and $13.6 \%$ of the total variance in faunal abundance respectively (Fig. 3). These two axes combined explained $78.4 \%$ of the variance in the species-environment relationship ( $46.7 \%$ and $31.7 \%$ respectively). Water temperature $\left({ }^{\circ} \mathrm{C}\right)$, magnesium $(\mathrm{mg} / \mathrm{l})$ and potassium $(\mathrm{mg} / \mathrm{l})$ were significantly correlated with the distribution of the groundwater fauna (all $p<0.01$ ). The stygobionts Niphargus kochianus, Microniphargus leruthi, Crangonyx subterraneus and

Proasellus cavaticus were associated with the centroids for the sandstone and carbonate hydro-units (hydro-unit 4 and 5). In contrast, some taxa were not strongly associated with the centroids of any single hydro-unit but were associated with higher concentrations of potassium ( $N$. fontanus and $N$. aquilex) and higher water temperature ( $N$. glenniei). Variance partitioning indicated that $7.5 \%$ of the variance in faunal abundance could be explained by the hydro-units and $5.0 \%$ by water chemistry (Table 5), whilst $3.6 \%$ of the variance was shared by hydro-units and water chemistry together.

Stygobionts and stygophiles were found throughout the region and were present in all hydro-units. However, stygobionts were absent from $70 \%$ of sites. Eberhard et al. (2009) and Hancock and Boulton (2009) found that repeated sampling over time at groundwater sites increased the number of species recorded, thus we cannot 
exclude the possibility that the low frequency of stygobiont occurrence in our study may be an artifact of low sampling effort, as we sampled each site on only one occasion.

We found that stygobiont occurrence and community composition differed between hydro-units. Stygobionts were significantly more likely to be recorded in the carbonate and igneous/metamorphic hydro-units, than in the mudstone/siltstone or sandstone units. Several stygobiont species (Niphargus kochianus, Microniphargus leruthi, Crangonyx subterraneus and Proasellus cavaticus) were predominantly associated with the carbonate hydro-unit. Other stygobionts (Niphargus aquilex and Niphargus glennieI) were found across a range of hydro-units.

The carbonate hydro-unit also supported the most diverse stygobiont communities, with up to four stygobiont species co-occurring in a single borehole. Carbonate aquifers are characterised by solutional fissures and conduits providing connected water-filled void spaces which are sufficiently large for groundwater organisms to inhabit (Humphreys 2009). Furthermore, their highly permeable nature may result in a greater supply of food from the surface, permitting the co-existence of more species than in less permeable hydro-units, where food shortages may be severe (Malard et al. 2009). Studies in continental Europe have demonstrated previously that karst aquifers support some of the most diverse stygobiont communities (DoleOlivier et al., 2009b; Martin et al., 2009; Galassi et al., 2009; Hahn and Fuchs, 2009).

The sandstone hydro-unit was also anticipated to provide a suitable habitat for diverse stygobiont communities because this has been the case in other regions (Humphreys 2009). Therefore, the low numbers of individuals and low diversity recorded in our study was surprising. One explanation is that the Permo-Triassic 
sandstones, which comprise part of this hydro-unit contain lower permeability mudstone beds in this area (Allen et al. 1997). This may result in a fragmented habitat with areas containing poorly developed fracture networks providing a poor habitat. The deposits are also affected by faulting which may result in further barriers to stygobiont movement. However, the sandstone (hydro-unit 4) is predominantly distributed in the west of the study area, which is outside the observed range of Niphargus kochianus, Niphargus fontanus and Proasellus cavaticus (Fig. 2), three of the most common stygobite species in the east of the study area. It is not clear whether the absence of these species in the west is because the sandstones do not form a suitable habitat for them, or because they have not dispersed to these areas.

The mudstone/siltstone hydro-unit had the lowest occurrence of stygobionts suggesting that it provides a less suitable habitat, perhaps as a result of the small and often weakly connected voids, and the low levels of oxygen and nutrients. Our findings are consistent with those of Hahn and Fuchs (2009), who also reported that mudstones were characterized by depauperate communities.

Our results demonstrate that the five hydro-units had different water chemistries. Therefore it was not possible to determine whether differences in groundwater fauna occurred due to water chemistry differences between the units, or differences between the physical voids present within the different units (Maurice and Bloomfield, 2012). However, in this study, groundwater taxa occurred in all units and the proportion of the variance in the abundance of the groundwater community explained by water chemistry was smaller than that of the hydro-units. The mudstone/siltstone and sandstone units remained significantly different from the 
427 carbonate unit in the general linear model, irrespective of the addition of water 428 chemistry parameters. However, the igneous/ metamorphic unit only became significantly separated from the other hydro units when potassium (together with sample type) was included in the model. The higher potassium concentrations reported from the igneous/ metamorphic hydro-unit relative to the carbonate hydrounit reflects the contrasting water chemistry of these different geologies. These findings provide evidence that suggests that, across our study sites, water chemistry had less influence over the distribution of groundwater taxa than physical hydrogeological characteristics. Other studies have also found little relation between environmental variables, water chemistry and the distribution of groundwater taxa at a regional scale (e.g. Dumas and Lescher-Moutoue 2001, Paran et al. 2005, DoleOlivier et al. 2009b, Galassi et al. 2009). Nevertheless, in all these studies there are considerable difficulties when trying to separate the influence of potentially confounding factors that occur over a range of geographical scales that may determine stygobiont distributions (Dole-Olivier et al., 2009b; Stoch and Galassi, 2010; Maurice and Bloomfield, 2012).

The probability of finding stygobionts appeared to increase with an increase in calcium concentrations. This is probably because stygobionts were most often found in the carbonate hydro-unit where calcium concentrations are high. Although calcium is necessary for crustacean carapace development (Rukke, 2002), it does not appear to be limiting in our study area as high stygobiont frequencies were also recorded from the igneous/metamorphic hydro-unit, where the mean calcium concentration was the lowest of all the hydro-units sampled. 
452 In contrast to Dole-Olivier et al. (2009b), we found no significant relationship

453 between dissolved oxygen concentration and stygobiont occurrence. This is probably because all but 14 of our sites had oxygen concentrations $>1 \mathrm{mgl}^{-1}$, which is the threshold below which oxygen has been reported to be critical for groundwater taxa (Malard and Hervant 1999, Hahn 2006). In addition, stygobionts are widely acknowledged to be tolerant of low oxygen conditions in comparison to epigean species (Malard and Hervant 1999).

The greater likelihood of finding stygobionts in spring sites (sample type 3) than in borehole sites (sample type 1) may be because it is easier to capture fauna in springs than in boreholes, and also because springs form a distinct ecotone where there are higher nutrients and more diverse communities than in deeper groundwaters (Smith et al. 2003) However, the use of springs as an explanatory variable did not fundamentally modify or significantly influence the differences we identified between the hydro-units.

Most of the variation in the occurrence of groundwater fauna across the study region was not explained by either the hydro-units or water chemistry. One of our most striking findings was the differing distribution patterns of stygobiont species within the study area. Most stygobiont species had restricted, and different distributions. The exception was Niphargus aquilex which was recorded from all hydro-units and across the whole study area. This species is widely distributed in central and southern Europe also (Botosaneanu 1986), with an apparent range that spans > $2300 \mathrm{~km}$ east - west (Trontelj et al. 2009). In the British Isles it has been extensively recorded in riverine hyporheic zones and is particularly associated with shallow alluvial aquifers (Proudlove et al. 2003) and, thus, may have dispersed across the 
477 area using this route (the hyporheic corridor concept of Stanford and Ward 1993).

478 Nevertheless, recent research shows that the wide distribution of Niphargus aquilex

479 is an artifact generated by cryptic diversity; the complex contains seven cryptic taxa,

480 two of which are unique to the British Isles (Mclnerney et al. 2014). Other widely

481 distributed Niphargus "species" have also been found to be species complexes (e.g.

N. virei, Lefebure et al. 2006 and N. rhenorhodanensis,Lefebure et al 2007, see also Trontelj et al. 2009).

Although there would appear to be suitable habitats distributed across the study area, other stygobiont species exhibited distinct spatial segregation. The endemic Niphargus. glenniei was only recorded in the west and Niphargus kochianus, Niphargus fontanus, and Proasellus cavaticus were only found in the east. One possible explanation for these observed distributions is that they result from biotic interactions between the species. Niphargus glenniei for example, did not co-occur with either Niphargus fontanus or Niphargus kochianus. Niphargus fontanus is much larger and may have a competitive or predatory advantage. However, stygobiont species can co-exist, and up to four species were found in a single borehole in the east of our study area. Although in our study Niphargus glenniei was mostly recorded alone or occasionally together with the smaller species Microniphargus leruthi, other studies have reported it with the larger species Niphargus aquilex (http://hcrs.freshwaterlife.org/). An alternative hypothesis is that geological barriers are present that constrain the dispersal of these organisms, as has been reported for other groundwater taxa (Gooch and Hetrick 1979; Goricki and Trontelj 2006). 500 Trontelj et al. (2009) observed that many groundwater taxa appear to be able to disperse and yet are confined by boundaries beyond which dispersal is impossible 
502 (although the nature of these boundaries is currently unclear). The 503 mudstones/siltstones and other low permeability rocks across the centre of our study

504 area may form a barrier between suitable stygobiont habitats in the east and west, and could explain the different species distributions. However, given the occurrence of all stygobiont species in spring habitats, it is surprising that groundwater species have not been able to utilize shallow superficial deposits (e.g. hyporheic zone corridors) to disperse between the east and west of the study area.

The life histories and restricted distributions of groundwater taxa mean that they are vulnerable to anthropogenic change (Gibert et al. 1994). Niphargus glenniei, which is endemic to two counties in southern England, has been designated a UK Biodiversity Action Plan species. However, other groundwater taxa have no such recognition, and European groundwater monitoring programmes do not consider groundwater ecology. Identifying the drivers of observed distribution patterns in groundwater taxa is important because this information may then be used to inform the development of management plans for the conservation of these unique assemblages.

.

CONCLUSIONS

In our regional scale study, there were significant differences in the groundwater assemblages present in geologies with different hydrogeological characteristics.

Stygobionts occurred most frequently and were most diverse in the carbonate hydrounit (5) which is characterized by karstic, solutionally enlarged voids providing an extensive physical habitat, and a good supply of nutrients and oxygen. They were also relatively abundant and diverse in the igneous and metamorphic hydro-unit (2) and granular aquifers (hydro-unit 1) but were relatively rare in the sandstone hydro- 
unit (4). They occurred least frequently in the mudstone/ siltstone hydro-unit (3) which has low permeability resulting in poor physical and water chemistry conditions for stygobionts. The hydro-units explained a greater proportion of the variation in stygobiont data than water chemistry, suggesting that physical hydrogeology may be more important than water chemistry in determining stygobiont distributions. However, a large proportion of the variation in stygobiont abundance was not related to either the hydro-units or water chemistry and we were intrigued to find that some stygobiont species were spatially segregated within our study area. It appears that barriers may exist that prevent some stygobiont taxa from colonizing apparently suitable geologies, and the low permeability deposits dividing the western and eastern parts of the study area may partly explain the observed distributions. The stygobiont species fell into three contrasting groups: (1) Niphargus glenniei was only found in the west of the study area, but was found in a range of hydro-units with varying void types and water chemistry.

(2) Niphargus kochianus, Niphargus fontanus, Crangonyx subterraneus and Proasellus cavaticus were only found in the east of the study area and predominantly in carbonate aquifers.

(3) Niphargus aquilex and Microniphargus leruthi, were found throughout the study area and in a range of hydro-units suggesting that they have good dispersal abilities and may be able to circumvent low permeability barriers, perhaps by utilizing superficial deposits these restricted and vulnerable species. 
551 This research was funded by the Esmee Fairbairn Foundation, grant number 08-

552

101,7 to ALR, PJW, LK and LM. We thank the many landowners who gave us permission to cross their land, and the Environment Agency for their help and assistance in accessing sites and provision of equipment. L. Maurice publishes with the permission of the Executive Director, British Geological Survey (NERC).

(1)

Allen, D.J., L.J. Brewerton, L.M. Coleby, B.R. Gibbs, M.A. Lewis, A.M. MacDonald, S.J. Wagstaff, and Williams, A.T., 1997. The physical properties of the major aquifers in England and Wales. BGS Technical Report WD/97/34, Environment Agency R\&D Publication 8. $312 \mathrm{pp}$

Botosaneanu, L. 1986. Stygofauna Mundi. E.J. Brill, Leiden.

Borcard, D., P. Legendre, and P. Drapeau, 1992. Partialling out the spatial component of ecological variation. Ecology 73:1045-1055.

Boutin, C., and N. Coineau. 1990. "Regression model, "modèle biphase" d'évolution et origine des microorganismes stygobies interstitiels continentaux. Revue de Micropaléontologie 33:303-322

Castellarini, F., F. Malard, M-J. Dole-Olivier, and J. Gibert. 2007. Modelling the distribution of stygobionts in the Jura Mountains (eastern France). Implications for the protection of ground waters. Diversity and Distributions 13:213-224.

Culver D.C., T. Pipan, and K. Schneider. 2009. Vicariance, dispersal and scale in the aquatic subterranean fauna of karst regions. Freshwater Biology 54:918-929.

Datry, T., F. Malard, and J. Gibert. 2005. Response of invertebrate assemblages to increased groundwater recharge rates in a phreatic aquifer. Journal of the North American Benthological Society 24:461-477. 
Dole-Olivier, M-J., F. Castellarini, N. Coineau, D.M.P. Galassi, P. Martin, N. Mori, A. Valdecasas, and J.Gibert. 2009a. Towards an optimal sampling strategy to assess groundwater biodiversity: comparison across six European regions. Freshwater Biology 54:777-796.

Dole-Olivier, M.-J., F. Malard, D. Martin, T. Lefebure, and J. Gibert. 2009b.

Relationships between environmental variables and groundwater biodiversity at the regional scale. Freshwater Biology 54:797-81

Dumas, P., and F. Lescher-Moutoue. 2001. Cyclopoid distribution in an agriculturally impacted alluvial aquifer. Archiv für Hydrobiologie 150:511-528.

Eberhard, S. M., S.A. Halse, M.R. Williams, M.D. Scanlon, J. Cocking, and H.J.

Barron. 2009. Exploring the relationship between sampling efficiency and shortrange endemism for groundwater fauna in the Pilbara region, Western Australia. Freshwater Biology 54:885-901.

Galassi, D.M.P., F. Stoch, B. Fiasca, T. Di Lorenzo, and E. Gattone. 2009.

Groundwater biodiversity patterns in the Lessinian Massif of northern Italy. Freshwater Biology 54:830-847.

Gibert, J., D. Danielpol, and J. Stanford (Eds). 1994. Groundwater Ecology. Academic Press LTD, London UK. pp1-551.

Gibert, J., D.C. Culver, M-J. Dole-Olivier, F. Malard, M.C. Christman, and L.

597 Gibert, J., and L. Deharveng. 2002. Subterranean ecosystems: A truncated Deharveng. 2009. Assessing and conserving groundwater biodiversity: synthesis functional biodiversity. Bioscience 52:473-481.

Gledhill, T., D.W. Sutcliffe, and W.D. Williams.1993. British Freshwater Crustacea Malacostraca: A key with ecological notes. Freshwater Biological Association 
601 Gooch J.L., and S.W. Hetrick. 1979. The Relation of Genetic Structure to

602 Environmental Structure: Gammarus minus in a KarstArea. Evolution 33:192-206.

603 Goricki, S., and P. Trontelj. 2006. Structure and evolution of the mitochondrial control

604 region and flanking sequences in the European cave salamander Proteus

605 anguinus. Gene 378:31-41.

606 Hahn, H.J. 2006. The GW-Fauna-Index: A first approach to a quantitative ecological

607 assessment of groundwater habitats. Limnologica 36:119-137.

608 Hahn, H.J., and A. Fuchs, 2009. Distribution patterns of groundwater communities

609 across aquifer types in south-western Germany. Freshwater Biology 54:848-860.

610 Hancock, P.J., and A.J. Boulton. 2009. Sampling groundwater fauna: efficiency of

611 rapid assessment methods tested in bores in eastern Australia. Freshwater

$612 \quad$ Biology 54:902-917.

613 Holsinger J.R.1988. Troglobites: The evolution of cave dwellin organisms. American

$614 \quad$ Scientist 76:146-153.

615 Humphreys W.F. 2009. Hydrogeology and groundwater ecology: Does each inform

616 the other? Hydrogeology Journal 17:5-21

617 Jaume, D., and W.F. Humphreys. 2001. A new genus of epacteriscid calanoid

618 copepod from an anchialine sinkhole in northwestern Australia. Journal of

619 Crustacean Biology 21:157-169.

620 Knight, L.R.F.D. and T. Gledhill. 2010. The discovery of Microniphargus leruthi

621 Schellenberg, 1934 (Crustacea: Amphipoda: Niphargidae) in Britain and its 622 distribution in the British Isles. Zootaxa 2655:52-56.

623 Kristjansson B.K., and J. Svavarsson. 2007. Sub-glacial refugia in Iceland enabled 624 groundwater amphipods to survive glaciations. American Naturalist 170:292-296. 
Larned S.T. 2012. Phreatic groundwater ecosystems: research frontiers for freshwater ecology. Freshwater Biology 57:885-906.

Lefébure, T., C.J. Douady, M. Gouy, P. Trontelj, J. Briolay, and J. Gibert. 2006. Phylogeography of a subterranean amphipod reveals cryptic diversity and dynamic evolution in extreme environments. Molecular Ecology 15:1797-1806.

Lefébure, T., C.J. Douady, F. Malard, and J. Gibert. 2007. Testing dispersal and cryptic diversity in a widely distributed groundwater amphipod (Niphargus rhenorhodanensis) Molecular Phylogenetics and Evolution 42:676-686.

Lesnoff, M., Lancelot, R. (2012). aod: Analysis of Overdispersed Data. R package version 1.3, URL http://cran.r-project.org/package=aod

Malard, F., and F. Hervant. 1999. Oxygen supply and the adaptations of animals in groundwater. Freshwater Biology 41:1-30.

Malard, F., C. Boutin, A.I. Camacho, D. Ferreira, G. Michel, B. Sket, and F. Stoch. 2009. Diversity patterns of stygobiotic crustaceans across multiple scales in Europe. Freshwater Biology 54: 756-776.

Martin, P., C. De Broyer, F. Fiers, G. Michel, R. Sablon, and K. Wouters. 2009. Biodiversity of Belgian groundwater fauna in relation to environmental conditions. Freshwater Biology 54:814-829.

Mauclaire, L. and J. Gibert. 2001. Environmental determinants of bacterial activity and faunal assemblages in alluvial riverbank aquifers. Archiv für Hydrobiologie 152:469-487.

Maurice, L. and J. Bloomfield. 2012. Stygobitic invertebrates in groundwater - A review from a hydrogeological perspective. Freshwater Reviews 5:51-71. 
Maurice, L.D., T.C. Atkinson, J.A. Barker, J.P. Bloomfield, A.R. Farrant, and A.T. Williams. 2006. Karstic behaviour of groundwater in the English Chalk. Journal of Hydrology. 330: 63-70.

Mclnerney C.E., L. Maurice, A.L. Robertson, L.R.F.D. Knight, J. Arnsheidt, C. Venditti, J.S.G. Dooley, T. Mathers, S. Matthijs , K. Erikkson, G. Proudlove and B. Hänfling (2014) The ancient Britons: Groundwater fauna survived extreme climate changes over tens of millions of years across NW Europe. Molecular Ecology 23: 1153-1166.

Moldovan O.T., I.N. Meleg, and A. Persoiu. 2012. Habitat fragmentation and its effect on groundwater populations. Ecohydrology 5:445-452.

Notenboom, J., 1991. Marine regressions and the evolution of groundwater dwelling amphipods (crustacea). Journal of Biogeography 18:437-454.

Paran F., F. Malard J. Mathieu, M. Lafont, D.M. P. Galassi, and P. Marmonier. 2005. Distribution of groundwater invertebrates along an environmental gradient in a shallow water-table aquifer. Pages 99-105 in J. Gibert (editor) World Subterranean Biodiversity, Proceedings of an International Symposium (Ed. J. Gibert) University Claude Bernard, Lyon, France

Price M. 1996. Introducing Groundwater, $2^{\text {nd }}$ edn. Chapman and Hall, London. pp 70-87.

Proudlove, G.S., P.J. Wood, P.T. Harding, D.J. Horne, T. Gledhill, and L.R.F.D. Knight.2003. A review of the status and distribution of the subterranean aquatic Crustacea of Britain and Ireland. Cave and Karst Science 30:51-74

R Core Team (2013). R: A language and environment for statistical computing. R Foundation for Statistical Computing, Vienna, Austria. URL http://www.R-proje ct.org/. 
673 Robertson, A. L., J.W.N. Smith, T. Johns, and G.S. Proudlove. 2009. The distribution 674 and diversity of stygobites in Great Britain: an analysis to inform groundwater management. Quarterly Journal of Engineering Geology and Hydrogeology 42:359-368.

Rukke, N.A. 2002. Effects of low calcium concentration on two common freshwater crustaceans, Gammarus lacustris and Astacus astacus. Functional Ecology 16:357-366.

Scheidleder, A., and P. Visser, 2012. Comparative Study of Pressures and

Schminke, H,K. 1974. Mesozoic Intercontinental Relationships as Evidenced by Bathynellid Crustacea (Syncarida : Malacostraca). Systematic Biology 23:157164.

Sket, B. 2004. Biodiversity in hypogean waters page 709. In: J. Gunn (editor) Encyclopedia of Caves and Karst Science. Fitzroy Dearborn, New York,

Smith, H., P.J. Wood, and J. Gunn 2003. The influence of habitat structure and flow permanence on invertebrate communities in karst spring systems. Hydrobiologia 510: 53-66.

Stanford, J.A., and J.V. Ward. 1993. An ecosystem perspective of alluvial rivers; connectivity and the hyporheic corridor. Journal of the North American Benthological Society 12:48-60.

Stock, J., 1980. Regression model evolution as exempliWed by the genus Pseudoniphargus (Amphipoda). Bijdragen tot de Dierkunde 50:105-144. 
697

698

699

700

701

702

703

704

705

706

707

708

709

710

711

712

713

Stoch, F., and D.M.P. Galassi, 2010. Stygobiotic crustacean species richness: a question of numbers, a matter of scale. Hydrobiologia 653:217-234.

Strayer, D.L., 1994. Limits to biological distributions in groundwater. in J. Gibert, D. Danielopol and J. Stanford. (editors) Groundwater Ecology. Academic Press Limited, London. U.K. pp 287-310.

ter Braak, C.J.F and P. Smilauer. 1998. CANOCO reference manual and user's guide to Canoco for windows: software for canonical community ordination (version 4). Wageningen.

Trontelj, P., C.J. Douady, C. Fiser, J. Gibert, S. Goricki, T. Lefebure, B. Sket, and V. Zaksek,V., 2009. A molecular test for cryptic diversity in ground water: how large are the ranges of macro-stygobionts? Freshwater Biology 54:727-744.

Ward, J.V., and M.A. Palmer. 1994. Distribution patterns of interstitial freshwater meiofauna over a range of spatial scales, with emphasis on alluvial river-aquifer systems. Hydrobiologia. 287:147-156. 
715 Figure 1: Distribution of groundwater fauna sampling stations and hydro-units within 716 the study region in the south-west of England.

717 Figure 2: Stygobitic species presence and community composition at sites within the 718 study region in the south-west of England. The size of the circles reflects the 719 number of species recorded.

720 Fig. 3: CCA ordination: Ordination by canonical correspondence analysis of 721 stygobiont species and stygophile data with significant environmental variables

722 (identified using the forward selection procedure) from boreholes, wells and springs 723 in SW England (Sept 2009-Nov 2011). 
725 Table 1: Classification and description of the 5 hydro-units in the study area

\begin{tabular}{|c|c|c|c|c|c|}
\hline $\begin{array}{l}\text { Hydro- } \\
\text { unit } \\
\text { (no.of } \\
\text { sites) }\end{array}$ & Geology & $\begin{array}{l}\text { Main } \\
\text { geologies }\end{array}$ & $\begin{array}{l}\text { \% Area } \\
\text { coverage }\end{array}$ & Flow & $\begin{array}{l}\text { Permeability } \\
\text { (relative) }\end{array}$ \\
\hline $1(10)$ & Granular & $\begin{array}{l}\text { Quaternary \& } \\
\text { Palaeogene } \\
\text { unconsolidated material }\end{array}$ & 6.3 & intergranular & Low-high \\
\hline $2(37)$ & $\begin{array}{l}\text { Igneous \& } \\
\text { metamorphic }\end{array}$ & $\begin{array}{l}\text { Granite, basalt, spillite \& } \\
\text { gneiss \& mica schists }\end{array}$ & 8.6 & Fracture & Low-mid \\
\hline $3(57)$ & $\begin{array}{l}\text { Mudstones \& } \\
\text { siltstones }\end{array}$ & $\begin{array}{l}\text { Carboniferous, Triassic \& } \\
\text { Jurassic mudstones }\end{array}$ & 51.6 & $\begin{array}{l}\text { Fracture and } \\
\text { intergranular }\end{array}$ & Very low \\
\hline $4(55)$ & Sandstones & $\begin{array}{l}\text { Permo-Triassic, Jurassic } \\
\text { \& Devonian sandstones }\end{array}$ & 17.2 & $\begin{array}{l}\text { Fracture and } \\
\text { intergranular }\end{array}$ & Mid-high \\
\hline $5(63)$ & $\begin{array}{l}\text { Carbonate } \\
\text { rocks }\end{array}$ & $\begin{array}{l}\text { Chalk, Carboniferous \& } \\
\text { Devonian limestones }\end{array}$ & 16.4 & $\begin{array}{l}\text { Karstic } \\
\text { (solutional } \\
\text { fissures and } \\
\text { conduits) }\end{array}$ & Low-high \\
\hline
\end{tabular}


728 Table 2: Means and standard deviations of water chemistry parameters for each hydro729 unit. Kruskal-wallis results indicate where determinands were significantly different 730 between hydro-units.

731

\begin{tabular}{|c|c|c|c|c|c|c|c|c|c|c|c|c|c|c|}
\hline $\begin{array}{c}\text { Hydro- } \\
\text { Unit }\end{array}$ & Statistic & $\begin{array}{c}\text { EC } \\
\mu \mathrm{Scm}^{-1}\end{array}$ & $\begin{array}{l}\text { DO } \\
\mathrm{mg} / \mathrm{l}\end{array}$ & $\begin{array}{c}\text { Temp } \\
{ }^{\circ} \mathrm{C}\end{array}$ & $\mathrm{pH}$ & $\begin{array}{l}\mathrm{DOC} \\
\mathrm{mg} / \mathrm{l}\end{array}$ & $\begin{array}{l}\mathrm{NH}_{4} \\
\mathrm{mg} / \mathrm{l}\end{array}$ & $\begin{array}{c}\mathrm{Cl} \\
\mathrm{mg} / \mathrm{l}\end{array}$ & $\begin{array}{l}\mathrm{NO}_{3} \\
\mathrm{mg} / \mathrm{l}\end{array}$ & $\begin{array}{l}\mathrm{SO}_{4} \\
\mathrm{mg} / \mathrm{l}\end{array}$ & $\begin{array}{c}\mathrm{Ca} \\
\mathrm{mg} / \mathrm{l}\end{array}$ & $\begin{array}{l}\mathrm{Mg} \\
\mathrm{mg} / \mathrm{l}\end{array}$ & $\begin{array}{c}\mathbf{K} \\
\mathrm{mg} / \mathrm{l}\end{array}$ & $\begin{array}{c}\mathrm{Na} \\
\mathrm{mg} / \mathrm{l}\end{array}$ \\
\hline \multirow{3}{*}{1} & $n$ & 8 & 8 & 8 & 8 & 8 & 8 & 8 & 8 & 8 & 8 & 8 & 8 & 8 \\
\hline & Mean & 370.25 & 3.65 & 13.71 & 7.04 & 3.63 & 0.52 & 9.59 & 7.46 & 10.29 & 47.51 & 3.53 & 3.76 & 16.00 \\
\hline & $\begin{array}{l}\text { Std } \\
\text { Dev. }\end{array}$ & 199.84 & 3.58 & 0.55 & 0.73 & 1.19 & 0.74 & 3.90 & 4.67 & 10.43 & 26.88 & 3.12 & 3.51 & 5.57 \\
\hline
\end{tabular}

\begin{tabular}{lllllccccccccccc}
\hline $\mathbf{2}$ & $\mathbf{n}$ & 37 & 14 & 23 & 36 & 32 & 13 & 37 & 30 & 32 & 32 & 32 & 27 & 33 \\
& Mean & 276.14 & 8.91 & 9.65 & 6.35 & 1.41 & 0.02 & 8.86 & 4.66 & 4.42 & 25.07 & 12.33 & 4.95 & 20.46 \\
& Std & 193.32 & 3.41 & 1.36 & 0.76 & 1.72 & 0.01 & 7.18 & 4.85 & 3.36 & 12.37 & 13.98 & 6.11 & 14.47 \\
& Dev. & & & & & & & & & & &
\end{tabular}

\begin{tabular}{llccccccccccccc}
\hline 3 & $\mathbf{n}$ & 47 & 29 & 29 & 45 & 47 & 29 & 46 & 41 & 47 & 46 & 46 & 45 & 45 \\
& Mean & 349.70 & 5.53 & 10.38 & 6.56 & 3.65 & 0.07 & 11.33 & 4.10 & 8.69 & 30.13 & 13.68 & 5.14 & 23.43 \\
& Std & 198.71 & 4.32 & 1.54 & 0.51 & 9.38 & 0.18 & 6.01 & 5.99 & 8.52 & 16.80 & 9.93 & 6.49 & 13.73 \\
Dev. & & & & & & & & & & &
\end{tabular}

\begin{tabular}{llcccccccccccccc}
\hline $\mathbf{n}$ & 37 & 24 & 26 & 37 & 39 & 6 & 40 & 26 & 37 & 38 & 38 & 34 & 38 \\
& Mean & 423.89 & 5.90 & 10.60 & 6.81 & 11.52 & 0.82 & 12.14 & 9.07 & 11.04 & 37.68 & 7.40 & 5.92 & 18.22 \\
& Std & 245.74 & 3.89 & 1.44 & 0.75 & 15.48 & 1.63 & 6.77 & 8.30 & 12.87 & 27.10 & 5.21 & 7.63 & 9.23 \\
& Dev. & & & & & & & & & & &
\end{tabular}

\begin{tabular}{llccccccccccccc}
\hline $\mathbf{5}$ & $\mathbf{n}$ & 54 & 25 & 39 & 54 & 54 & 17 & 55 & 53 & 52 & 53 & 52 & 43 & 53 \\
& Mean & 582.96 & 5.69 & 11.50 & 7.09 & 12.37 & 0.10 & 11.81 & 9.35 & 6.76 & 55.64 & 4.51 & 4.08 & 15.79 \\
& Std & 133.64 & 3.14 & 0.82 & 0.43 & 31.16 & 0.11 & 6.02 & 5.52 & 4.49 & 21.89 & 4.25 & 3.21 & 8.82 \\
& Dev. & & & & & & & & & &
\end{tabular}

\begin{tabular}{rlccccccccccccc}
\hline Kruskal & $\mathbf{H}$ & 48.54 & 11.36 & 22.37 & 30.49 & 53.51 & $\mathrm{~N} / \mathrm{A}$ & 14.25 & 38.66 & 18.56 & 44.73 & 36.24 & 5.51 & 13.44 \\
Wallis & $\mathbf{D f}$ & 4 & 4 & 4 & 4 & 4 & & 4 & 4 & 4 & 4 & 4 & 4 & 4 \\
Test & $\boldsymbol{p}$ & $<0.001$ & $<0.001$ & $<0.001$ & $<0.001$ & $<0.001$ & & $<0.01$ & $<0.001$ & $<0.01$ & $<0.001$ & $<0.001$ & 0.239 & $<0.01$
\end{tabular}

$732 \quad$ N/A - insufficient data (majority of values below detection limit). 
735 Table 3: Abundance and composition of groundwater taxa (stygobionts and

736 stygophiles) in boreholes $(\mathrm{BH})$, wells and springs from the five hydro-units.

737

Attributes of sample sites

Sites sampled (no.)

\begin{tabular}{lllll} 
& Total & BHs & Wells & Springs \\
\hline No. of sites sampled: & 221 & 124 & 56 & 41 \\
No. of sites in each hydro-unit (Hu) & & & & \\
Granular (Hu1) & 10 & 9 & 1 & 0 \\
Igneous/metamorphic (Hu2) & 37 & 12 & 12 & 13 \\
Mudstone/siltstone (Hu3) & 56 & 28 & 19 & 9 \\
Sandstone (Hu4) & 55 & 34 & 11 & 10 \\
Carbonate (Hu5) & 63 & 41 & 13 & 9 \\
No. of sites with GW fauna & 155 & 70 & 51 & 34 \\
Sites with no GW fauna ${ }^{1}$ & 66 & 54 & 5 & 7 \\
No. of sites with stygobionts & 75 & 34 & 23 & 18
\end{tabular}

\begin{tabular}{lcccccc}
\hline Taxa groups \& species & $\begin{array}{l}\text { Total } \\
\text { Abundance }\end{array}$ & \multicolumn{2}{l}{$\begin{array}{l}\text { Percentage occurrence from all sites } \\
\text { Hydro-units }\end{array}$} \\
\hline Stygobionts & 465 & 33.8 & 27.4 & 40.4 & 43.9 & All \\
present
\end{tabular}

Crustacea, Malacostraca, Eumalacostraca

\section{Peracarida}

Amphipoda,

Niphargidae

$\begin{array}{lllllll}\text { Niphargus kochianus } & 181 & 10.8 & 12.9 & 12.3 & 2.5 & 3,5 \\ \text { Niphargus fontanus } & 28 & 5.4 & 4.8 & 7.0 & 4.9 & 1,5 \\ \text { Niphargus aquilex } & 96 & 10.4 & 8.1 & 12.3 & 14.6 & 1,2,3,4,5 \\ \text { Niphargus glenniei } & 79 & 8.6 & 2.4 & 12.3 & 22.0 & 2,3,4,5 \\ \text { Microniphargus leruthi } & 10 & 2.7 & 2.4 & 3.5 & 2.5 & 3,4,5 \\ \text { Crangonycitidae } & & & & & & 4,5 \\ \text { Crangonyx subterraneus } & 60 & 5.9 & 6.5 & 3.5 & 7.3 & 4,5\end{array}$

Isopoda

Asellidae

Proasellus cavaticus

10

2.3

$4.0 \quad 0$

0

5

Syncarida

Bathynellacea,

Bathynellidae 


$\begin{array}{lllllll}\text { Antrobathynella stammeri } & 1 & 0.5 & 0.8 & 0 & 0 & 4 \\ \text { Stygophiles } & 5318 & 63.5 & 44.4 & 86.0 & 90.2 & \text { All }\end{array}$

Crustacea, Maxillopoda

$\begin{array}{lllllll}\text { Copepoda } & 4181 & 47.3 & 26.6 & 70.2 & 78.0 & 1,2,3,4,5 \\ \text { Crustacea, Ostracoda } & 745 & 23.4 & 8.1 & 38.6 & 48.8 & 1,2,3,4,5\end{array}$

Arthropoda, Arachnida, Acari, Trombidiformes

Hydrachnidae

182

210

10.4

12.9

12.3

$2,3,4,5$

738

${ }^{* 1}$ Other freshwater (epigean) or terrestrial taxa may have been recorded at these sites

739

$*^{2}$ Not included where recovered from spring sources, due to presence of epigean species 
741 Table 4: Summary of odds ratios from generalized linear models selected to describe

742 relationships between presence/absence data, hydro-units $\mathrm{(Hu}$ and water chemistry.

743 (The level of significance reported in each model is represented by: ${ }^{*} 0.05,{ }^{* \star} 0.01$, $744 * \star * 0.001)$.

Odds ratios calculated relative to: 


\begin{tabular}{|c|c|c|c|c|c|c|c|}
\hline $\begin{array}{l}\text { Generalized linear model } \\
\text { (simplest model selected } \\
\text { based on comparison of all } \\
\text { model permutations) }\end{array}$ & $\begin{array}{l}\text { Determinand } \\
\text { (value) }\end{array}$ & 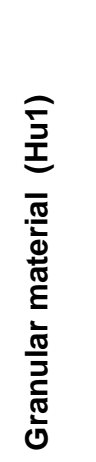 & 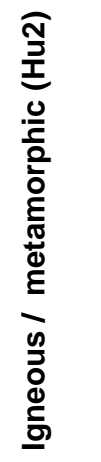 & 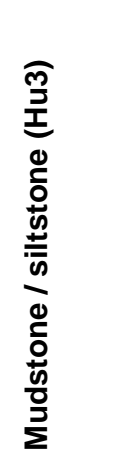 & 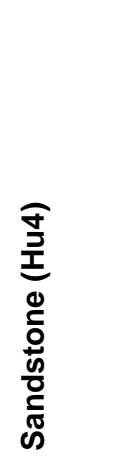 & 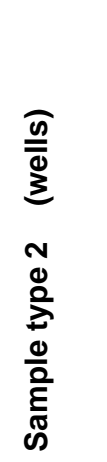 & 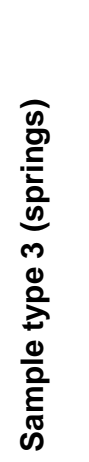 \\
\hline \multirow{4}{*}{$\begin{array}{l}\text { Pres/Abs Hydro-unit } \\
\chi^{2}=33.8, \mathrm{df}=5, p<0.001\end{array}$} & all data & 0.84 & 0.80 & $0.12^{\star \star \star}$ & $0.21^{\star \star \star}$ & & \\
\hline & dissolved oxygen & 2.00 & 1.00 & $0.16^{\star \star}$ & $0.26^{*}$ & & \\
\hline & nitrate & $\mathrm{N} / \mathrm{A}$ & 0.67 & $0.12^{\star \star \star}$ & $0.28 *$ & & \\
\hline & temperature & 2.38 & 1.48 & $0.15^{\star \star}$ & $0.23^{*}$ & & \\
\hline \multirow[t]{3}{*}{ Pres/Abs Hydro-unit + value } & calcium & 0.97 & 0.98 & $0.18^{\star *}$ & $0.27^{\star \star}$ & & \\
\hline & chloride & 0.93 & 0.63 & $0.11^{\star \star}$ & $0.20 * \star$ & & \\
\hline & $\mathrm{pH}$ & 0.96 & 0.56 & $0.08^{\star \star \star}$ & $0.16^{\star \star \star}$ & & \\
\hline \multirow[t]{6}{*}{ Pres/Abs Hydro-unit + sample type } & $\begin{array}{l}\text { Dissolved organic } \\
\text { carbon }\end{array}$ & 1.12 & 0.65 & $0.10^{\star * \star}$ & $0.21^{\star \star *}$ & $2.34^{*}$ & $3.01^{*}$ \\
\hline & elec. conductivity & 1.09 & 0.59 & $0.10^{\star \star \star}$ & $0.22^{* *}$ & 2.19 & 3.07 * \\
\hline & magnesium & 0.94 & 0.43 & $0.10^{* *}$ & $0.19^{\star \star *}$ & 1.83 & $3.22^{*}$ \\
\hline & potassium & 0.91 & $0.30 *$ & $0.07^{\star \star \star *}$ & $0.14^{\star \star *}$ & 1.77 & $4.52^{*}$ \\
\hline & sodium & 1.00 & 0.49 & $0.12^{\star \star \star}$ & $0.21^{\star *}$ & 1.92 & $3.20^{*}$ \\
\hline & sulphate & 1.89 & 0.49 & $0.09 * \star \star$ & $0.19 * *$ & 1.86 & $3.51 *$ \\
\hline
\end{tabular}

$746 \quad$ N/A - excluded from analysis because insufficient reliable nitrate data available

747 Level of significance in model ${ }^{*} 0.05,{ }^{* \star} 0.01,{ }^{* \star *} 0.001$

748

749

750

751

752

753

754 
756 Table 5: Partialled CCA results showing percentage of variation in species data explained

757 by environmental variables; hydro-units \& groundwater chemistry, together and in isolation.

758

$\begin{array}{clllll}\text { CCA } & \begin{array}{l}\text { Constraint on } \\ \text { Species data }\end{array} & \begin{array}{l}\text { Variable } \\ \text { partialled out } \\ \text { (covariable) }\end{array} & \begin{array}{l}\text { Sum of all } \\ \text { canonical } \\ \text { eigen-values } \\ \text { (Ev) }\end{array} & \begin{array}{l}\text { Percentage } \\ \text { variation } \\ \text { (Ev } x\end{array} & \begin{array}{l}\text { Fraction of variation } \\ \text { explained by }\end{array} \\ & & & \text { 100/4.998) } & \end{array}$

\begin{tabular}{lllllc}
\hline CCA1 & Chemistry & none & 0.429 & $8.58 \%$ & - \\
CCA2 & Hydro-units & none & 0.628 & $12.57 \%$ & - \\
CCA3 & Hydro-units & Chemistry & 0.251 & $5.02 \%$ & Chemistry \\
CCA4 & Chemistry & Hydro-units & 0.376 & $7.52 \%$ & Hydro-units
\end{tabular}

Sum of all eigenvalues in a species only CA $\quad 4.998$

Overall amount of variation due to environmental variables

$16.11 \%$

CCA1 + CC4

Variation due to hydro-units \& water chemistry together

$3.56 \%$

CCA1 - CCA3

Variation unexplained by hydro-units \&/or water chemistry

$83.89 \%$

$100-(\mathrm{CCA} 1+\mathrm{CCA} 4)$ 
Figure 1: Groundwater faunal records and distribution of hydro-units within the study region in the south-west of England.

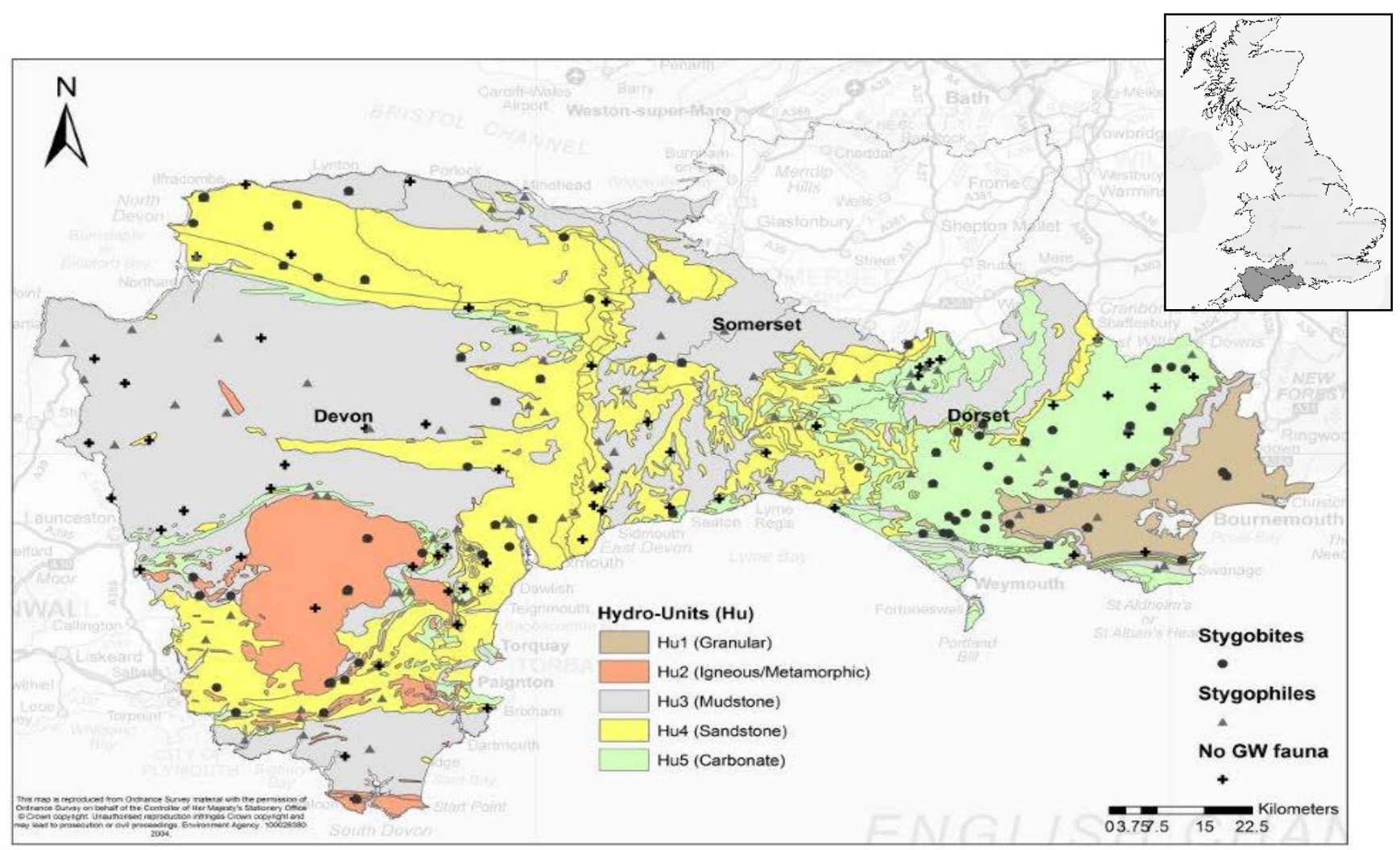

Figure 2: Stygobitic species presence and community composition at sites within the study region in the south-west of England. The size of the circles reflects the number of species recorded.

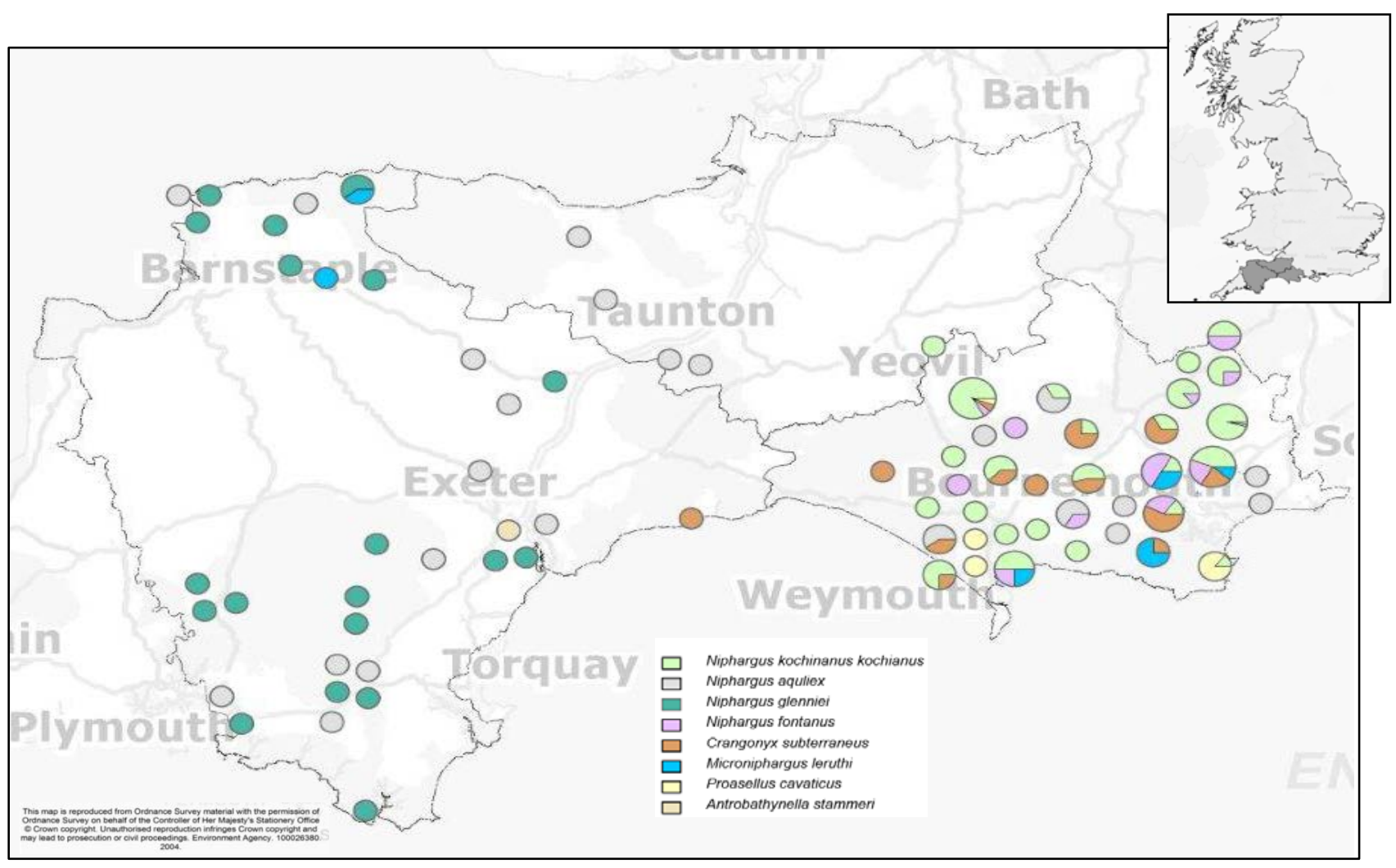


1 Running head: Groundwater faunal distributions

2

3 REGIONAL SCALE DRIVERS OF GROUNDWATER FAUNAL DISTRIBUTIONS

4

5 Tim Johns ${ }^{1,6}$, J. Iwan Jones $^{2}$, Lee Knight ${ }^{3}$, Louise Maurice ${ }^{4}$, Paul Wood $^{5}$, Anne

6 Robertson $^{6 *}$

7 1. Environment Agency, Red Kite House, Howbery Park, Wallingford, Oxfordshire,

8 OX10 8BD, UK.

9 2. School of Biological and Chemical Sciences, Queen Mary University of London, 10 London E14NS

11 3. No. 1 The Linhay, North Kenwood Farm, Oxton, Nr Kenton, Devon, EX6 8EX

12 4. British Geological Survey, Maclean Building, Crowmarsh Gifford, Wallingford, 13 Oxfordshire, OX10 8BB UK.

14 5. Centre for Hydrological and Ecosystems Science, Department of Geography,

15 Loughborough University, Loughborough, Leicestershire, LE11 3TU, UK 6* Department of Life Sciences, University of Roehampton, Holybourne Avenue, London SW15 4JD, UK. T: +44 (0) 2083923456 E: a.robertson@roehampton.ac.uk *Author to whom correspondence should be addressed 
Freshwater aquifers are a major source of drinking water; they also possess unique assemblages of organisms. However, little is known about the distributional drivers of obligate groundwater organisms at the regional scale. We examine the distribution and composition of stygobiont assemblages in a complex geological setting and explore the relationship between groundwater fauna, hydrogeology and water chemistry. In the study area we grouped similar geologies into five hydrogeological formations (hydro-units) within which habitats for groundwater fauna were broadly similar. We found that the occurrence of stygobionts differed significantly between hydro-units. Stygobionts were significantly less likely to be recorded in mudstone/siltstone and sandstone aquifers compared with carbonate rocks or with igneous/metamorphic rocks. Variance partitioning indicated that the hydro-units explained a greater proportion of the variance $(7.52 \%)$ in the groundwater community than water chemistry (5.02\%). However, much of the variation remained unexplained. The macrofaunal stygobiont species in our study area formed three groups: (1) Niphargus glenniei was recorded in a range of hydrounits but only in the west of the study area. (2) Niphargus kochianus, Niphargus fontanus, Proasellus cavaticus and Crangonyx subterraneus were predominately recorded in carbonate aquifers in the east of the study area. (3) Niphargus aquilex and Microniphargus leruthi, were found throughout the study area and in a range of hydro-units. We hypothesise that physical barriers exist that prevent some stygobiont taxa from colonizing apparently suitable geologies; the low permeability deposits dividing the western and eastern parts of the study area may partly explain the observed distributions. 
KEYWORDS

52 Hydrogeology, Geology, British Isles, Devon, Dorset, Stygobionts, Stygophiles, Niphargus, Water chemistry, groundwater. 
Freshwater aquifers represent approximately $65 \%$ of drinking water sources in the

EU (Scheidleder and Visser, 2012), and thus their hydrogeology and chemistry are generally well known. In addition to their value as a resource, groundwaters possess unique assemblages of organisms and globally harbour a large reservoir of biodiversity with a high proportion of endemic and rare species compared with surface water habitats (Sket 2004, Gibert et al. 2009). In response to the energy poor nature of subterranean environments, groundwater invertebrates typically have low population densities and extended life histories with delayed maturity, greater longevity, smaller egg-clutch size, larger eggs and lower percentages of mature ovigerous females than related surface-dwelling (epigean) species (Gibert et al. may result in an increased vulnerability to anthropogenic impacts compared to epigean taxa. This vulnerability may be compounded by their slow dispersal rates (Culver et al. 2009).

Although research centred on surface-groundwater interactions is burgeoning and has moved from descriptive studies to a more experimental approach (introduction to this special issue, Larned 2012), research into deeper groundwaters is less developed, perhaps because of the difficulties in accessing this environment. Despite numerous studies describing the occurrence and distribution of groundwater fauna (e.g. Botosaneanu 1986, Proudlove et al. 2003, Robertson et al 2009, Gibert et al. 2009), relatively little is known about the environmental and/or historical drivers of their distribution patterns. The relative importance of a given driver is likely to vary across spatial and temporal scales. At the continental scale, stygobiont distribution 
patterns have been shaped by events in deep geological time, for example the movement of continental plates (e.g. Schminke 1974), orogenic and eustatic events (Stock 1980, Boutin and Coineau 1990, Notenboom 1991), and the alternation of marine transgressions and regressions (e.g. Jaume and Humphreys 2001). Long term climate change has also shaped the distribution of groundwater taxa. In the northern hemisphere the Pleistocene glaciations appear to have had a catastrophic effect on groundwater communities, leaving Northern Europe with a depauperate groundwater fauna compared to the rest of Europe. For example, only eight species of obligate groundwater macro Crustacea have been recorded from mainland Britain, including four species of Niphargus, the most speciose groundwater genus (Proudlove et al. 2003, Robertson et al. 2009, Knight and Gledhill 2010). This contrasts with 134 species of Niphargus recorded in the Balkans biogeographical area (McInerney et al. 2014). In Northern Europe, contemporary distributions reflect patterns of past glacial activity (e.g. Strayer 1994, Robertson et al. 2009). However, there are some species present in formerly deglaciated areas, and those species that remain in Northern Europe must have survived the impacts of glacial and periglacial conditions (Holsinger 1988, Proudlove et al. 2003, Kristjansson and Svavarsson 2007, Lefebure et al. 2007, Mclnerney et al. 2014). Indeed, recent research has shown that the small number of Niphargus species that are present in the UK are ancient endemics that have survived millions of years of extreme climate changes (Mclnerney et al. 2014). At smaller scales, stygobiont distribution patterns are influenced by the availability of suitable habitat and aquifer connectivity as well as the ecological tolerances, competitive interactions and dispersal abilities of species (Gibert et al. 1994, Castellarini et al. 2007, Hahn and Fuchs 2009). 
104 Regional investigations that have gathered large datasets on stygobiont presence and environmental conditions are relatively rare (Mauclaire and Gibert 2001, Galassi et al. 2009, Martin et al. 2009, Dole-Olivier et al. 2009b, Hahn and Fuchs 2009). In these studies, geology appears to be an important determinant of stygobiont distributions because it controls the availability of suitable habitats (Datry et al. 2005, Dole-Olivier et al. 2009b, Botosaneanu 1986, Hahn and Fuchs 2009). Most stygobionts are dependent on well-developed void spaces with wide pore throats or fracture apertures. These features commonly occur in karstic, porous and fractured aquifers and this is where obligate groundwater communities are most diverse and abundant (e.g. Gibert and Deharveng 2002, Dole-Olivier et al. 2009b). In addition to providing physical habitat, the degree to which void spaces are developed and connected also influences the exchange of oxygen, nutrients and organic matter with the surface, and thus the availability of food for the groundwater community.

Observed distribution patterns may also relate to the opportunities for dispersal. In groundwaters the habitat is very fragmented, limiting the dispersal of groundwater fauna (Lefebure et al. 2007). Stygobiont assemblages are therefore characterised by endemic species with limited geographical ranges. Even species which are apparently widely distributed have emerged as cryptic lineages (Lefebure et al. 2007, Trontelj et al. 2009, Mclnerney et al. 2014). Habitat fragmentation in groundwaters has been most frequently discussed in relation to karst habitats (Trontelj et al. 2009, Modovan et al. 2012), however it may also occur as a result of the juxtaposition of different geologies. The presence of mudstones with low permeability and restricted void spaces may form a physical barrier to stygobiont dispersal (Hahn and Fuchs 2009). Some stygobiont taxa, however, may be able to exploit superficial deposits or the hyporheic zones of rivers as a means of dispersal (e.g. Ward and Palmer 1994, 
129 Castellarini et al. 2007). The water chemistry of an aquifer, e.g. concentrations of dissolved organic carbon and nitrates, may also correlate with the distribution of groundwater taxa (Martin et al. 2009).

In this study we address the limited understanding of the drivers of groundwater faunal distributions at the regional scale by carrying out an extensive sampling programme within the complex geological setting of the south-west of the UK. Our aims were to determine the detailed spatial distributions of the UK stygobiont species in the study area and investigate whether the distribution and composition of stygobiont assemblages varies with hydrogeology and water chemistry. We build on the design of the PASCALIS project on European groundwater biodiversity which adopted a hierarchical sampling strategy and included two types of aquifer (porous and karstic) (Dole-Olivier et al. 2009a). Our approach was to group the different hydrogeological formations present in the study area into five 'hydro-units' where the different geologies within a given hydro-unit provide broadly similar habitats for groundwater fauna. We sampled groundwater assemblages within the different hydro-units to determine whether species were restricted to particular hydro-units, and sampled water chemistry to determine whether faunal distributions reflect local variation in water chemistry.

\section{METHODS}

\section{Study area and hydrogeological units}

151 The study area in south west England is an area of contrasting topography and geology dominated by lowland (max. elevation $279 \mathrm{~m}$ ) sedimentary rocks in the east and higher elevation (max. $621 \mathrm{~m}$ ) metamorphic and igneous rocks in the west (Fig. 
1). The region's annual average rainfall is approximately $900-1000 \mathrm{~mm}$ (http://www.metoffice.gov.uk/climate/uk/sw/).

Within the study area 271 different geological formations have been mapped at the 1:50,000 scale (Reproduced from the British Geological Survey Map data at the original scale of 1:50 000 Licence 2011/057 British Geological Survey. @NERC. All rights reserved). To assess the general hydrogeological controls on species distributions, these geologies were grouped into categories termed "hydro-units". The hydro-units are based on broad differences in geology and groundwater flow characteristics which result in different groundwater habitats for fauna. There are two main types of groundwater flow: intergranular and flow through fractures (Price 1996). Unconsolidated granular deposits in which all groundwater movement is intergranular were grouped together as hydro-unit 1 because these deposits form a habitat in which fauna can only live within the pore spaces between the sediment (hydro-unit 2) because there were insufficient data to determine differences in habitat type between them. They were grouped separately from other strata because groundwater flow is only through fractures, and due to of their volcanic origin, they have a bedrock geochemistry that is different to other consolidated rocks. Sedimentary rocks may be non-carbonate or carbonate. Non-carbonate sedimentary rocks often have varying degrees of consolidation and, therefore, form aquifers in which flow may be both inter-granular in the less consolidated areas and through fractures in consolidated rock. They are classified according to grain size as mudstones, siltstones and sandstones (Price 1996). Sandstones form aquifers with 
much higher permeability than siltstones and mudstones which often form aquitards or aquicludes (Price 1996, Allen et al. 1997). The difference in permeability is likely to result in both a different groundwater chemistry and a different physical habitat for fauna. They were therefore separated into a mudstone/siltstone hydro-unit (3) and a sandstone hydro-unit (4). Hydro-unit 5 includes all carbonate geologies. In these rocks, fractures are enlarged by dissolution to form fissures and caves providing substantially larger and more inter-connected void spaces than any other rock type, which can serve as habitats for fauna. In the study area carbonate rocks range from the weakly karstified Cretaceous Chalk (Maurice et al, 2006) to the highly karstified limestones of Devonian and Carboniferous. Where the Chalk overlies the Upper Greensand Formation these strata are commonly in hydraulic continuity (Allen et al. 1997). This means that it is likely that fauna may be living in both the Chalk and the Upper Greensand, and that it is not possible to distinguish the two habitats. The Upper Greensand Formation is a non-karstic aquifer comprising sandstones and sands, but where it is in hydraulic continuity with the Chalk it was included in the carbonate hydro-unit (5). Elsewhere, outcrops of the Upper Greensand Formation are isolated from the Chalk and, were therefore grouped with the other sandstones in the sandstone hydro-unit (4). The properties of the five hydro-units are summarized in Table 1.

The distribution and extent of the different hydro-units varied across the study area (Fig. 1). In particular there was a pronounced difference between the hydro-units in the east and west of the study area. Mudstones/siltstones (hydro-unit 3), covered the largest surface area in the study region and were most common in the west. Sandstones (hydro-unit 4), were the next most common, and occurred across the 
region, with the largest outcrops in the west and north-west. Carbonate aquifers (hydro-unit 5), were predominately located in the east, where there were extensive Cretaceous chalk downlands. In the west carbonate rocks were limited to much smaller isolated outcrops of older limestones, separated by mudstones and sandstones. Granular material (hydro-unit 1) was restricted to the far south eastern were only present in the west and south west.

\section{Sampling}

In total, 221 sites were sampled. The number of samples taken within each hydrounit was approximately proportionate to the surface area it occupied (Table 1). Within each unit, sites were selected to maximize spatial coverage. Boreholes free from fine mesh well screens and in-situ equipment were preferentially selected. Borehole and well sampling sites ranged from 0.36 to $130 \mathrm{~m}$ deep and 0.05 to $2 \mathrm{~m}$ in diameter. Where there were insufficient boreholes or wells, springs were sampled. Each site was sampled on a single occasion. Most samples (197) were collected between September 2009 and May 2010, and water chemistry measurements were made at water chemistry data were obtained for these samples.

Fauna were collected from boreholes and wells using a weighted plankton net $(63 \mu \mathrm{m}$ mesh, diameter varied from $35-300 \mathrm{~mm}$ dependent on borehole aperture). The net was lowered to the base of the borehole/well and moved up and down vigorously to

227 disturb the sediment before retrieval. For springs, a net was swept through the sediment of the spring chamber or at the spring head source. The samples were 
preserved in $>90 \%$ ethanol and all equipment thoroughly cleaned between sites. In the laboratory animals were separated from debris, stygobionts were identified to species level using Gledhill et al. (1993) and Knight and Gledhill (2010); Ostracoda (identified to class), Hydracarina (identified to clade) and Copepoda and Oligochaeta (identified to sub-class) were probably predominantly stygophiles and stygoxenes. Freshwater epigean taxa and terrestrial taxa were noted.

Electrical conductivity, $\mathrm{pH}$, dissolved oxygen and temperature were recorded using a multi-parameter probe (YSI 600QS) lowered to the base of each borehole/well. The probe was calibrated prior to each sampling trip. Water samples for laboratory analysis were taken using a bailer. At springs, field chemistry and water samples were taken directly from the spring head or catchpit. Water samples were filtered and refrigerated before dispatch to analytical laboratories within 48 hours. Analysis for major anions $\left(\mathrm{Cl}^{-}, \mathrm{SO}_{4}{ }^{2-}, \mathrm{NO}_{3}{ }^{-}\right)$and cations $\left(\mathrm{Mg}^{2+}, \mathrm{K}^{+}, \mathrm{Na}^{+}, \mathrm{Ca}^{2+}\right)$ was performed using high pressure liquid chromatography using a Dionex ED40 electrochemical segmented flow analyser (min. reporting value $0.2 \mathrm{mgl}^{-1}$ ).

Data analysis

Chemical data were tested for normality (Q-Q plots) and homogeneity of variance (Fligner- Killeen test), and a non-parametric ANOVA was used to investigate differences in water chemistry between the five different hydro-units (selected as factors). A generalized linear model with a binomial error structure was then used to examine the relationships between presence/absence of stygobiont taxa, hydro-units 
and water chemistry. Statistical analyses were performed using R version 3.0.2 (2013), using standard packages plus the package for analysis of over dispersed data (Lesnoff et al, 2012). The initial model selected hydro-unit as a factor. The model was then run with all stygobiont presence/absence data, using the carbonate hydro-unit (5) as the point of comparison because it: i) comprised the most sites, ii) was the strata in which stygobionts were most common, and iii) also yielded a broad range of water quality data. Models were then run for each set of water quality data (i.e. each chemical determinand with associated presence/absence and hydro-unit data), the odds ratios were calculated and predicted probabilities of stygobiont presence were determined from the mean value for each determinand. Different permutations of the model were run to explore whether the inclusion of sample type (borehole, well or spring) and/or water quality data improved the model, and to identify any interactions between factors. Outputs were checked to verify the data were not over dispersed and models were then compared, using a one-way ANOVA, describe the relative likelihood of recording stygobionts in each hydro-unit.

The association between the faunal community and environmental variables was investigated using Canonical Correspondence Analysis (CCA) within Canoco for Windows Ver.4.51 (Ter Braak and Smilauer 1998). Only those sites with concurrent chemistry analysis (190 samples) were used in this analysis and sites where there was uncertainty over the geological unit from which the sample was obtained ( 7 samples) were excluded. 
278 A series of ordinations were undertaken including groundwater faunal abundance, hydro-units and water chemistry data. Both stygobiont and stygophile taxa were included in the analysis to reflect the diversity and distribution of the community recorded from each sample location where fauna were recorded, although the results and discussion are focused on the stygobiont taxa. To determine how individual variables might explain patterns in the faunal data (stygobionts and stygophiles), we applied the forward selection procedure ( $\mathrm{P} \leq 0.05$ after Bonferonni correction). Only those variables having a significant association with the faunal community distribution were included in the final analysis and presented in the output diagrams. The stygobiont Antrobathynella stammeri (Jakobi, 1954), which was recorded only once, was fitted passively to the ordination. To determine the proportion of variance in the faunal data explained by the hydro-units and water chemistry data, a variance partitioning approached was used (Borcard 1992). This constrained the species ordination for each of these co-variable groups in turn, while partialling out the other variables from the ordination.

As expected water chemistry varied significantly between the five hydro-units, reflecting differences in bedrock geochemistry and permeability. With the exception of potassium, significant differences were recorded between each chemical determinand and the five hydro-units (Table 2).

Stygobionts and/or stygophiles were recorded from $70 \%$ of the study sites (Table 3 ) and all hydro-units (Fig.1). The remaining $30 \%$ of sites contained no groundwater 
taxa although epigean taxa were recorded at some sites. Stygophiles were more abundant and recorded more frequently than stygobionts (59\% compared to $34 \%$ of sites). All of the stygobiont macro-Crustacea known to occur in the UK were recorded, although their presence and community composition varied considerably across the study region. Boreholes in the carbonate hydro-unit (unit 5) supported the most diverse stygobiont communities, with up to four taxa recorded in a single borehole, compared to a maximum of two taxa from other hydro-units (Fig. 2).

Niphargus aquilex (Schiödte, 1855), was recorded throughout the study region and from all hydro-units (Fig. 2). In contrast, Niphargus glenniei (Spooner, 1952) was only recorded in the west of the study area despite being recorded in most hydrounits. Niphargus kochianus (Bate, 1859), Niphargus fontanus (Bate, 1859) and Proasellus cavaticus (Leydig, 1871) were primarily recorded in the carbonate hydrounit (5) in the east of the region (Fig. 2), but were absent from this hydro-unit and all other hydro-units in the west of the study area. Crangonyx subterraneus (Bate, 1859) and Microniphargus leruthi (Schellenberg 1934) were rare, and were primarily recorded in the east (Fig. 2). Antrobathynella stammeri (Jakobi, 1954) was recorded once.

The occurrence of stygobionts differed significantly between hydro-units $\left[\chi^{2}=33.8\right.$, $d f=5, p<0.001$, Table 4]. From the odds ratio (OR), stygobionts were $88 \%$ less likely to be recorded in mudstone/siltstones (hydro-unit 3) [OR=0.12, $97.5 \% \mathrm{Cl} 0.034-$ $0.030, p<0.001$ ] than in carbonates (hydro-unit 5 ) and about $80 \%$ less likely to be recorded in sandstones (hydro-unit 4) [OR=0.20,97.5\% Cl 0.08-0.50, $p<0.001]$, than carbonates (hydro-unit 5). Stygobionts were also less likely to be recorded in 
mudstones/siltstones (hydro-unit 3) and sandstones (hydro-unit 4) than in igneous/metamorphic sites (hydro-unit 2) and granular sites (hydro-unit 1). All differences were significant except for sandstone sites relative to granular sites. The generalized linear model generally improved (based on the AIC scores and level of significance) with the addition of either sample type or a water chemistry determinand as a value. Mudstones/siltstones and sandstones (hydro-units 3 and 4) were significantly different from carbonate rocks (hydro-unit 5) throughout the iterations. No significant interactions between factors (e.g. hydro-unit combined with sample type) were identified. By including water chemistry determinands with presence/absence in the model, improved models were obtained with calcium, chloride and $\mathrm{pH}$, indicating a potential association of these variables with stygobiont presence. The predicted probability of stygobiont presence in any hydro-unit was higher with increasing calcium concentrations. In contrast, the predicted probability of stygobiont presence in any hydro-unit declined as chloride concentrations increased. There was no clear relationship between $\mathrm{pH}$ and the presence of stygobionts.

The inclusion of sample type significantly improved the models that included electrical conductivity, magnesium, potassium, sodium, sulphate and dissolved organic carbon. For the model with potassium, the igneous/metamorphic aquifers (hydro-unit 2) were identified as significantly different when sample type was included. The odds ratio of recording stygobionts in this unit was also lower compared with the simplest model where no additional factors were included. Overall there was a greater likelihood of recording stygobionts in springs (sample type 3) than boreholes (sample type 1: Table 4). However, presence or absence of 
stygobionts across the hydro-units was significant $(p<0.001)$ irrespective of the inclusion of sample type in the model.

Canonical correspondence analysis indicated a separation of the sample centroids for the five hydro-units based on the faunal community data (Fig. 3), the first two canonical axes explained $20.0 \%$ and $13.6 \%$ of the total variance in faunal abundance respectively (Fig. 3). These two axes combined explained $78.4 \%$ of the variance in the species-environment relationship ( $46.7 \%$ and $31.7 \%$ respectively). Water temperature $\left({ }^{\circ} \mathrm{C}\right)$, magnesium $(\mathrm{mg} / \mathrm{l})$ and potassium $(\mathrm{mg} / \mathrm{l})$ were significantly correlated with the distribution of the groundwater fauna (all $p<0.01$ ). The stygobionts Niphargus kochianus, Microniphargus leruthi, Crangonyx subterraneus and

Proasellus cavaticus were associated with the centroids for the sandstone and carbonate hydro-units (hydro-unit 4 and 5). In contrast, some taxa were not strongly associated with the centroids of any single hydro-unit but were associated with higher concentrations of potassium ( $N$. fontanus and $N$. aquilex) and higher water temperature ( $N$. glenniei). Variance partitioning indicated that $7.5 \%$ of the variance in faunal abundance could be explained by the hydro-units and $5.0 \%$ by water chemistry (Table 5), whilst $3.6 \%$ of the variance was shared by hydro-units and water chemistry together.

Stygobionts and stygophiles were found throughout the region and were present in all hydro-units. However, stygobionts were absent from $70 \%$ of sites. Eberhard et al. (2009) and Hancock and Boulton (2009) found that repeated sampling over time at groundwater sites increased the number of species recorded, thus we cannot 
exclude the possibility that the low frequency of stygobiont occurrence in our study may be an artifact of low sampling effort, as we sampled each site on only one occasion.

We found that stygobiont occurrence and community composition differed between hydro-units. Stygobionts were significantly more likely to be recorded in the carbonate and igneous/metamorphic hydro-units, than in the mudstone/siltstone or sandstone units. Several stygobiont species (Niphargus kochianus, Microniphargus leruthi, Crangonyx subterraneus and Proasellus cavaticus) were predominantly associated with the carbonate hydro-unit. Other stygobionts (Niphargus aquilex and Niphargus glennieI) were found across a range of hydro-units.

The carbonate hydro-unit also supported the most diverse stygobiont communities, with up to four stygobiont species co-occurring in a single borehole. Carbonate aquifers are characterised by solutional fissures and conduits providing connected water-filled void spaces which are sufficiently large for groundwater organisms to inhabit (Humphreys 2009). Furthermore, their highly permeable nature may result in a greater supply of food from the surface, permitting the co-existence of more species than in less permeable hydro-units, where food shortages may be severe (Malard et al. 2009). Studies in continental Europe have demonstrated previously that karst aquifers support some of the most diverse stygobiont communities (DoleOlivier et al., 2009b; Martin et al., 2009; Galassi et al., 2009; Hahn and Fuchs, 2009).

The sandstone hydro-unit was also anticipated to provide a suitable habitat for diverse stygobiont communities because this has been the case in other regions (Humphreys 2009). Therefore, the low numbers of individuals and low diversity recorded in our study was surprising. One explanation is that the Permo-Triassic 
sandstones, which comprise part of this hydro-unit contain lower permeability mudstone beds in this area (Allen et al. 1997). This may result in a fragmented habitat with areas containing poorly developed fracture networks providing a poor habitat. The deposits are also affected by faulting which may result in further barriers to stygobiont movement. However, the sandstone (hydro-unit 4) is predominantly distributed in the west of the study area, which is outside the observed range of Niphargus kochianus, Niphargus fontanus and Proasellus cavaticus (Fig. 2), three of the most common stygobite species in the east of the study area. It is not clear whether the absence of these species in the west is because the sandstones do not form a suitable habitat for them, or because they have not dispersed to these areas.

The mudstone/siltstone hydro-unit had the lowest occurrence of stygobionts suggesting that it provides a less suitable habitat, perhaps as a result of the small and often weakly connected voids, and the low levels of oxygen and nutrients. Our findings are consistent with those of Hahn and Fuchs (2009), who also reported that mudstones were characterized by depauperate communities.

Our results demonstrate that the five hydro-units had different water chemistries. Therefore it was not possible to determine whether differences in groundwater fauna occurred due to water chemistry differences between the units, or differences between the physical voids present within the different units (Maurice and Bloomfield, 2012). However, in this study, groundwater taxa occurred in all units and the proportion of the variance in the abundance of the groundwater community explained by water chemistry was smaller than that of the hydro-units. The mudstone/siltstone and sandstone units remained significantly different from the 
427 carbonate unit in the general linear model, irrespective of the addition of water 428 chemistry parameters. However, the igneous/ metamorphic unit only became significantly separated from the other hydro units when potassium (together with sample type) was included in the model. The higher potassium concentrations reported from the igneous/ metamorphic hydro-unit relative to the carbonate hydrounit reflects the contrasting water chemistry of these different geologies. These findings provide evidence that suggests that, across our study sites, water chemistry had less influence over the distribution of groundwater taxa than physical hydrogeological characteristics. Other studies have also found little relation between environmental variables, water chemistry and the distribution of groundwater taxa at a regional scale (e.g. Dumas and Lescher-Moutoue 2001, Paran et al. 2005, DoleOlivier et al. 2009b, Galassi et al. 2009). Nevertheless, in all these studies there are considerable difficulties when trying to separate the influence of potentially confounding factors that occur over a range of geographical scales that may determine stygobiont distributions (Dole-Olivier et al., 2009b; Stoch and Galassi, 2010; Maurice and Bloomfield, 2012).

The probability of finding stygobionts appeared to increase with an increase in calcium concentrations. This is probably because stygobionts were most often found in the carbonate hydro-unit where calcium concentrations are high. Although calcium is necessary for crustacean carapace development (Rukke, 2002), it does not appear to be limiting in our study area as high stygobiont frequencies were also recorded from the igneous/metamorphic hydro-unit, where the mean calcium concentration was the lowest of all the hydro-units sampled. 
452 In contrast to Dole-Olivier et al. (2009b), we found no significant relationship

453 between dissolved oxygen concentration and stygobiont occurrence. This is probably because all but 14 of our sites had oxygen concentrations $>1 \mathrm{mgl}^{-1}$, which is the threshold below which oxygen has been reported to be critical for groundwater taxa (Malard and Hervant 1999, Hahn 2006). In addition, stygobionts are widely acknowledged to be tolerant of low oxygen conditions in comparison to epigean species (Malard and Hervant 1999).

The greater likelihood of finding stygobionts in spring sites (sample type 3) than in borehole sites (sample type 1) may be because it is easier to capture fauna in springs than in boreholes, and also because springs form a distinct ecotone where there are higher nutrients and more diverse communities than in deeper groundwaters (Smith et al. 2003) However, the use of springs as an explanatory variable did not fundamentally modify or significantly influence the differences we identified between the hydro-units.

Most of the variation in the occurrence of groundwater fauna across the study region was not explained by either the hydro-units or water chemistry. One of our most striking findings was the differing distribution patterns of stygobiont species within the study area. Most stygobiont species had restricted, and different distributions. The exception was Niphargus aquilex which was recorded from all hydro-units and across the whole study area. This species is widely distributed in central and southern Europe also (Botosaneanu 1986), with an apparent range that spans > $2300 \mathrm{~km}$ east - west (Trontelj et al. 2009). In the British Isles it has been extensively recorded in riverine hyporheic zones and is particularly associated with shallow alluvial aquifers (Proudlove et al. 2003) and, thus, may have dispersed across the 
477 area using this route (the hyporheic corridor concept of Stanford and Ward 1993).

478 Nevertheless, recent research shows that the wide distribution of Niphargus aquilex

479 is an artifact generated by cryptic diversity; the complex contains seven cryptic taxa,

480 two of which are unique to the British Isles (Mclnerney et al. 2014). Other widely

481 distributed Niphargus "species" have also been found to be species complexes (e.g.

N. virei, Lefebure et al. 2006 and N. rhenorhodanensis,Lefebure et al 2007, see also Trontelj et al. 2009).

Although there would appear to be suitable habitats distributed across the study area, other stygobiont species exhibited distinct spatial segregation. The endemic Niphargus. glenniei was only recorded in the west and Niphargus kochianus, Niphargus fontanus, and Proasellus cavaticus were only found in the east. One possible explanation for these observed distributions is that they result from biotic interactions between the species. Niphargus glenniei for example, did not co-occur with either Niphargus fontanus or Niphargus kochianus. Niphargus fontanus is much larger and may have a competitive or predatory advantage. However, stygobiont species can co-exist, and up to four species were found in a single borehole in the east of our study area. Although in our study Niphargus glenniei was mostly recorded alone or occasionally together with the smaller species Microniphargus leruthi, other studies have reported it with the larger species Niphargus aquilex (http://hcrs.freshwaterlife.org/). An alternative hypothesis is that geological barriers are present that constrain the dispersal of these organisms, as has been reported for other groundwater taxa (Gooch and Hetrick 1979; Goricki and Trontelj 2006). 500 Trontelj et al. (2009) observed that many groundwater taxa appear to be able to disperse and yet are confined by boundaries beyond which dispersal is impossible 
502 (although the nature of these boundaries is currently unclear). The 503 mudstones/siltstones and other low permeability rocks across the centre of our study

504 area may form a barrier between suitable stygobiont habitats in the east and west, and could explain the different species distributions. However, given the occurrence of all stygobiont species in spring habitats, it is surprising that groundwater species have not been able to utilize shallow superficial deposits (e.g. hyporheic zone corridors) to disperse between the east and west of the study area.

The life histories and restricted distributions of groundwater taxa mean that they are vulnerable to anthropogenic change (Gibert et al. 1994). Niphargus glenniei, which is endemic to two counties in southern England, has been designated a UK Biodiversity Action Plan species. However, other groundwater taxa have no such recognition, and European groundwater monitoring programmes do not consider groundwater ecology. Identifying the drivers of observed distribution patterns in groundwater taxa is important because this information may then be used to inform the development of management plans for the conservation of these unique assemblages.

.

CONCLUSIONS

In our regional scale study, there were significant differences in the groundwater assemblages present in geologies with different hydrogeological characteristics.

Stygobionts occurred most frequently and were most diverse in the carbonate hydrounit (5) which is characterized by karstic, solutionally enlarged voids providing an extensive physical habitat, and a good supply of nutrients and oxygen. They were also relatively abundant and diverse in the igneous and metamorphic hydro-unit (2) and granular aquifers (hydro-unit 1) but were relatively rare in the sandstone hydro- 
unit (4). They occurred least frequently in the mudstone/ siltstone hydro-unit (3) which has low permeability resulting in poor physical and water chemistry conditions for stygobionts. The hydro-units explained a greater proportion of the variation in stygobiont data than water chemistry, suggesting that physical hydrogeology may be more important than water chemistry in determining stygobiont distributions. However, a large proportion of the variation in stygobiont abundance was not related to either the hydro-units or water chemistry and we were intrigued to find that some stygobiont species were spatially segregated within our study area. It appears that barriers may exist that prevent some stygobiont taxa from colonizing apparently suitable geologies, and the low permeability deposits dividing the western and eastern parts of the study area may partly explain the observed distributions. The stygobiont species fell into three contrasting groups: (1) Niphargus glenniei was only found in the west of the study area, but was found in a range of hydro-units with varying void types and water chemistry.

(2) Niphargus kochianus, Niphargus fontanus, Crangonyx subterraneus and Proasellus cavaticus were only found in the east of the study area and predominantly in carbonate aquifers.

(3) Niphargus aquilex and Microniphargus leruthi, were found throughout the study area and in a range of hydro-units suggesting that they have good dispersal abilities and may be able to circumvent low permeability barriers, perhaps by utilizing superficial deposits these restricted and vulnerable species. 
551 This research was funded by the Esmee Fairbairn Foundation, grant number 08-

552

101,7 to ALR, PJW, LK and LM. We thank the many landowners who gave us permission to cross their land, and the Environment Agency for their help and assistance in accessing sites and provision of equipment. L. Maurice publishes with the permission of the Executive Director, British Geological Survey (NERC).

(1)

Allen, D.J., L.J. Brewerton, L.M. Coleby, B.R. Gibbs, M.A. Lewis, A.M. MacDonald, S.J. Wagstaff, and Williams, A.T., 1997. The physical properties of the major aquifers in England and Wales. BGS Technical Report WD/97/34, Environment Agency R\&D Publication 8. $312 \mathrm{pp}$

Botosaneanu, L. 1986. Stygofauna Mundi. E.J. Brill, Leiden.

Borcard, D., P. Legendre, and P. Drapeau, 1992. Partialling out the spatial component of ecological variation. Ecology 73:1045-1055.

Boutin, C., and N. Coineau. 1990. "Regression model, "modèle biphase" d'évolution et origine des microorganismes stygobies interstitiels continentaux. Revue de Micropaléontologie 33:303-322

Castellarini, F., F. Malard, M-J. Dole-Olivier, and J. Gibert. 2007. Modelling the distribution of stygobionts in the Jura Mountains (eastern France). Implications for the protection of ground waters. Diversity and Distributions 13:213-224.

Culver D.C., T. Pipan, and K. Schneider. 2009. Vicariance, dispersal and scale in the aquatic subterranean fauna of karst regions. Freshwater Biology 54:918-929.

Datry, T., F. Malard, and J. Gibert. 2005. Response of invertebrate assemblages to increased groundwater recharge rates in a phreatic aquifer. Journal of the North American Benthological Society 24:461-477. 
Dole-Olivier, M-J., F. Castellarini, N. Coineau, D.M.P. Galassi, P. Martin, N. Mori, A. Valdecasas, and J.Gibert. 2009a. Towards an optimal sampling strategy to assess groundwater biodiversity: comparison across six European regions. Freshwater Biology 54:777-796.

Dole-Olivier, M.-J., F. Malard, D. Martin, T. Lefebure, and J. Gibert. 2009b.

Relationships between environmental variables and groundwater biodiversity at the regional scale. Freshwater Biology 54:797-81

Dumas, P., and F. Lescher-Moutoue. 2001. Cyclopoid distribution in an agriculturally impacted alluvial aquifer. Archiv für Hydrobiologie 150:511-528.

Eberhard, S. M., S.A. Halse, M.R. Williams, M.D. Scanlon, J. Cocking, and H.J.

Barron. 2009. Exploring the relationship between sampling efficiency and shortrange endemism for groundwater fauna in the Pilbara region, Western Australia. Freshwater Biology 54:885-901.

Galassi, D.M.P., F. Stoch, B. Fiasca, T. Di Lorenzo, and E. Gattone. 2009.

Groundwater biodiversity patterns in the Lessinian Massif of northern Italy. Freshwater Biology 54:830-847.

Gibert, J., D. Danielpol, and J. Stanford (Eds). 1994. Groundwater Ecology. Academic Press LTD, London UK. pp1-551.

Gibert, J., D.C. Culver, M-J. Dole-Olivier, F. Malard, M.C. Christman, and L.

597 Gibert, J., and L. Deharveng. 2002. Subterranean ecosystems: A truncated Deharveng. 2009. Assessing and conserving groundwater biodiversity: synthesis functional biodiversity. Bioscience 52:473-481.

Gledhill, T., D.W. Sutcliffe, and W.D. Williams.1993. British Freshwater Crustacea Malacostraca: A key with ecological notes. Freshwater Biological Association 
601 Gooch J.L., and S.W. Hetrick. 1979. The Relation of Genetic Structure to

602 Environmental Structure: Gammarus minus in a KarstArea. Evolution 33:192-206.

603 Goricki, S., and P. Trontelj. 2006. Structure and evolution of the mitochondrial control

604 region and flanking sequences in the European cave salamander Proteus

605 anguinus. Gene 378:31-41.

606 Hahn, H.J. 2006. The GW-Fauna-Index: A first approach to a quantitative ecological

607 assessment of groundwater habitats. Limnologica 36:119-137.

608 Hahn, H.J., and A. Fuchs, 2009. Distribution patterns of groundwater communities

609 across aquifer types in south-western Germany. Freshwater Biology 54:848-860.

610 Hancock, P.J., and A.J. Boulton. 2009. Sampling groundwater fauna: efficiency of

611 rapid assessment methods tested in bores in eastern Australia. Freshwater

$612 \quad$ Biology 54:902-917.

613 Holsinger J.R.1988. Troglobites: The evolution of cave dwellin organisms. American

$614 \quad$ Scientist 76:146-153.

615 Humphreys W.F. 2009. Hydrogeology and groundwater ecology: Does each inform

616 the other? Hydrogeology Journal 17:5-21

617 Jaume, D., and W.F. Humphreys. 2001. A new genus of epacteriscid calanoid

618 copepod from an anchialine sinkhole in northwestern Australia. Journal of

619 Crustacean Biology 21:157-169.

620 Knight, L.R.F.D. and T. Gledhill. 2010. The discovery of Microniphargus leruthi

621 Schellenberg, 1934 (Crustacea: Amphipoda: Niphargidae) in Britain and its 622 distribution in the British Isles. Zootaxa 2655:52-56.

623 Kristjansson B.K., and J. Svavarsson. 2007. Sub-glacial refugia in Iceland enabled 624 groundwater amphipods to survive glaciations. American Naturalist 170:292-296. 
Larned S.T. 2012. Phreatic groundwater ecosystems: research frontiers for freshwater ecology. Freshwater Biology 57:885-906.

Lefébure, T., C.J. Douady, M. Gouy, P. Trontelj, J. Briolay, and J. Gibert. 2006. Phylogeography of a subterranean amphipod reveals cryptic diversity and dynamic evolution in extreme environments. Molecular Ecology 15:1797-1806.

Lefébure, T., C.J. Douady, F. Malard, and J. Gibert. 2007. Testing dispersal and cryptic diversity in a widely distributed groundwater amphipod (Niphargus rhenorhodanensis) Molecular Phylogenetics and Evolution 42:676-686.

Lesnoff, M., Lancelot, R. (2012). aod: Analysis of Overdispersed Data. R package version 1.3, URL http://cran.r-project.org/package=aod

Malard, F., and F. Hervant. 1999. Oxygen supply and the adaptations of animals in groundwater. Freshwater Biology 41:1-30.

Malard, F., C. Boutin, A.I. Camacho, D. Ferreira, G. Michel, B. Sket, and F. Stoch. 2009. Diversity patterns of stygobiotic crustaceans across multiple scales in Europe. Freshwater Biology 54: 756-776.

Martin, P., C. De Broyer, F. Fiers, G. Michel, R. Sablon, and K. Wouters. 2009. Biodiversity of Belgian groundwater fauna in relation to environmental conditions. Freshwater Biology 54:814-829.

Mauclaire, L. and J. Gibert. 2001. Environmental determinants of bacterial activity and faunal assemblages in alluvial riverbank aquifers. Archiv für Hydrobiologie 152:469-487.

Maurice, L. and J. Bloomfield. 2012. Stygobitic invertebrates in groundwater - A review from a hydrogeological perspective. Freshwater Reviews 5:51-71. 
Maurice, L.D., T.C. Atkinson, J.A. Barker, J.P. Bloomfield, A.R. Farrant, and A.T. Williams. 2006. Karstic behaviour of groundwater in the English Chalk. Journal of Hydrology. 330: 63-70.

Mclnerney C.E., L. Maurice, A.L. Robertson, L.R.F.D. Knight, J. Arnsheidt, C. Venditti, J.S.G. Dooley, T. Mathers, S. Matthijs , K. Erikkson, G. Proudlove and B. Hänfling (2014) The ancient Britons: Groundwater fauna survived extreme climate changes over tens of millions of years across NW Europe. Molecular Ecology 23: 1153-1166.

Moldovan O.T., I.N. Meleg, and A. Persoiu. 2012. Habitat fragmentation and its effect on groundwater populations. Ecohydrology 5:445-452.

Notenboom, J., 1991. Marine regressions and the evolution of groundwater dwelling amphipods (crustacea). Journal of Biogeography 18:437-454.

Paran F., F. Malard J. Mathieu, M. Lafont, D.M. P. Galassi, and P. Marmonier. 2005. Distribution of groundwater invertebrates along an environmental gradient in a shallow water-table aquifer. Pages 99-105 in J. Gibert (editor) World Subterranean Biodiversity, Proceedings of an International Symposium (Ed. J. Gibert) University Claude Bernard, Lyon, France

Price M. 1996. Introducing Groundwater, $2^{\text {nd }}$ edn. Chapman and Hall, London. pp 70-87.

Proudlove, G.S., P.J. Wood, P.T. Harding, D.J. Horne, T. Gledhill, and L.R.F.D. Knight.2003. A review of the status and distribution of the subterranean aquatic Crustacea of Britain and Ireland. Cave and Karst Science 30:51-74

R Core Team (2013). R: A language and environment for statistical computing. R Foundation for Statistical Computing, Vienna, Austria. URL http://www.R-proje ct.org/. 
673 Robertson, A. L., J.W.N. Smith, T. Johns, and G.S. Proudlove. 2009. The distribution 674 and diversity of stygobites in Great Britain: an analysis to inform groundwater management. Quarterly Journal of Engineering Geology and Hydrogeology 42:359-368.

Rukke, N.A. 2002. Effects of low calcium concentration on two common freshwater crustaceans, Gammarus lacustris and Astacus astacus. Functional Ecology 16:357-366.

Scheidleder, A., and P. Visser, 2012. Comparative Study of Pressures and

Schminke, H,K. 1974. Mesozoic Intercontinental Relationships as Evidenced by Bathynellid Crustacea (Syncarida : Malacostraca). Systematic Biology 23:157164.

Sket, B. 2004. Biodiversity in hypogean waters page 709. In: J. Gunn (editor) Encyclopedia of Caves and Karst Science. Fitzroy Dearborn, New York,

Smith, H., P.J. Wood, and J. Gunn 2003. The influence of habitat structure and flow permanence on invertebrate communities in karst spring systems. Hydrobiologia 510: 53-66.

Stanford, J.A., and J.V. Ward. 1993. An ecosystem perspective of alluvial rivers; connectivity and the hyporheic corridor. Journal of the North American Benthological Society 12:48-60.

Stock, J., 1980. Regression model evolution as exempliWed by the genus Pseudoniphargus (Amphipoda). Bijdragen tot de Dierkunde 50:105-144. 
697

698

699

700

701

702

703

704

705

706

707

708

709

710

711

712

713

Stoch, F., and D.M.P. Galassi, 2010. Stygobiotic crustacean species richness: a question of numbers, a matter of scale. Hydrobiologia 653:217-234.

Strayer, D.L., 1994. Limits to biological distributions in groundwater. in J. Gibert, D. Danielopol and J. Stanford. (editors) Groundwater Ecology. Academic Press Limited, London. U.K. pp 287-310.

ter Braak, C.J.F and P. Smilauer. 1998. CANOCO reference manual and user's guide to Canoco for windows: software for canonical community ordination (version 4). Wageningen.

Trontelj, P., C.J. Douady, C. Fiser, J. Gibert, S. Goricki, T. Lefebure, B. Sket, and V. Zaksek,V., 2009. A molecular test for cryptic diversity in ground water: how large are the ranges of macro-stygobionts? Freshwater Biology 54:727-744.

Ward, J.V., and M.A. Palmer. 1994. Distribution patterns of interstitial freshwater meiofauna over a range of spatial scales, with emphasis on alluvial river-aquifer systems. Hydrobiologia. 287:147-156. 
715 Figure 1: Distribution of groundwater fauna sampling stations and hydro-units within 716 the study region in the south-west of England.

717 Figure 2: Stygobitic species presence and community composition at sites within the 718 study region in the south-west of England. The size of the circles reflects the 719 number of species recorded.

720 Fig. 3: CCA ordination: Ordination by canonical correspondence analysis of 721 stygobiont species and stygophile data with significant environmental variables

722 (identified using the forward selection procedure) from boreholes, wells and springs 723 in SW England (Sept 2009-Nov 2011). 
725 Table 1: Classification and description of the 5 hydro-units in the study area

\begin{tabular}{|c|c|c|c|c|c|}
\hline $\begin{array}{l}\text { Hydro- } \\
\text { unit } \\
\text { (no.of } \\
\text { sites) }\end{array}$ & Geology & $\begin{array}{l}\text { Main } \\
\text { geologies }\end{array}$ & $\begin{array}{l}\text { \% Area } \\
\text { coverage }\end{array}$ & Flow & $\begin{array}{l}\text { Permeability } \\
\text { (relative) }\end{array}$ \\
\hline $1(10)$ & Granular & $\begin{array}{l}\text { Quaternary \& } \\
\text { Palaeogene } \\
\text { unconsolidated material }\end{array}$ & 6.3 & intergranular & Low-high \\
\hline $2(37)$ & $\begin{array}{l}\text { Igneous \& } \\
\text { metamorphic }\end{array}$ & $\begin{array}{l}\text { Granite, basalt, spillite \& } \\
\text { gneiss \& mica schists }\end{array}$ & 8.6 & Fracture & Low-mid \\
\hline $3(57)$ & $\begin{array}{l}\text { Mudstones \& } \\
\text { siltstones }\end{array}$ & $\begin{array}{l}\text { Carboniferous, Triassic \& } \\
\text { Jurassic mudstones }\end{array}$ & 51.6 & $\begin{array}{l}\text { Fracture and } \\
\text { intergranular }\end{array}$ & Very low \\
\hline $4(55)$ & Sandstones & $\begin{array}{l}\text { Permo-Triassic, Jurassic } \\
\text { \& Devonian sandstones }\end{array}$ & 17.2 & $\begin{array}{l}\text { Fracture and } \\
\text { intergranular }\end{array}$ & Mid-high \\
\hline $5(63)$ & $\begin{array}{l}\text { Carbonate } \\
\text { rocks }\end{array}$ & $\begin{array}{l}\text { Chalk, Carboniferous \& } \\
\text { Devonian limestones }\end{array}$ & 16.4 & $\begin{array}{l}\text { Karstic } \\
\text { (solutional } \\
\text { fissures and } \\
\text { conduits) }\end{array}$ & Low-high \\
\hline
\end{tabular}


728 Table 2: Means and standard deviations of water chemistry parameters for each hydro729 unit. Kruskal-wallis results indicate where determinands were significantly different 730 between hydro-units.

731

\begin{tabular}{|c|c|c|c|c|c|c|c|c|c|c|c|c|c|c|}
\hline $\begin{array}{c}\text { Hydro- } \\
\text { Unit }\end{array}$ & Statistic & $\begin{array}{c}\text { EC } \\
\mu \mathrm{Scm}^{-1}\end{array}$ & $\begin{array}{l}\text { DO } \\
\mathrm{mg} / \mathrm{l}\end{array}$ & $\begin{array}{c}\text { Temp } \\
{ }^{\circ} \mathrm{C}\end{array}$ & $\mathrm{pH}$ & $\begin{array}{l}\mathrm{DOC} \\
\mathrm{mg} / \mathrm{l}\end{array}$ & $\begin{array}{l}\mathrm{NH}_{4} \\
\mathrm{mg} / \mathrm{l}\end{array}$ & $\begin{array}{c}\mathrm{Cl} \\
\mathrm{mg} / \mathrm{l}\end{array}$ & $\begin{array}{l}\mathrm{NO}_{3} \\
\mathrm{mg} / \mathrm{l}\end{array}$ & $\begin{array}{l}\mathrm{SO}_{4} \\
\mathrm{mg} / \mathrm{l}\end{array}$ & $\begin{array}{c}\mathrm{Ca} \\
\mathrm{mg} / \mathrm{l}\end{array}$ & $\begin{array}{l}\mathrm{Mg} \\
\mathrm{mg} / \mathrm{l}\end{array}$ & $\begin{array}{c}\mathbf{K} \\
\mathrm{mg} / \mathrm{l}\end{array}$ & $\begin{array}{c}\mathrm{Na} \\
\mathrm{mg} / \mathrm{l}\end{array}$ \\
\hline \multirow{3}{*}{1} & $n$ & 8 & 8 & 8 & 8 & 8 & 8 & 8 & 8 & 8 & 8 & 8 & 8 & 8 \\
\hline & Mean & 370.25 & 3.65 & 13.71 & 7.04 & 3.63 & 0.52 & 9.59 & 7.46 & 10.29 & 47.51 & 3.53 & 3.76 & 16.00 \\
\hline & $\begin{array}{l}\text { Std } \\
\text { Dev. }\end{array}$ & 199.84 & 3.58 & 0.55 & 0.73 & 1.19 & 0.74 & 3.90 & 4.67 & 10.43 & 26.88 & 3.12 & 3.51 & 5.57 \\
\hline
\end{tabular}

\begin{tabular}{lllllccccccccccc}
\hline $\mathbf{2}$ & $\mathbf{n}$ & 37 & 14 & 23 & 36 & 32 & 13 & 37 & 30 & 32 & 32 & 32 & 27 & 33 \\
& Mean & 276.14 & 8.91 & 9.65 & 6.35 & 1.41 & 0.02 & 8.86 & 4.66 & 4.42 & 25.07 & 12.33 & 4.95 & 20.46 \\
& Std & 193.32 & 3.41 & 1.36 & 0.76 & 1.72 & 0.01 & 7.18 & 4.85 & 3.36 & 12.37 & 13.98 & 6.11 & 14.47 \\
& Dev. & & & & & & & & & & &
\end{tabular}

\begin{tabular}{llccccccccccccc}
\hline 3 & $\mathbf{n}$ & 47 & 29 & 29 & 45 & 47 & 29 & 46 & 41 & 47 & 46 & 46 & 45 & 45 \\
& Mean & 349.70 & 5.53 & 10.38 & 6.56 & 3.65 & 0.07 & 11.33 & 4.10 & 8.69 & 30.13 & 13.68 & 5.14 & 23.43 \\
& Std & 198.71 & 4.32 & 1.54 & 0.51 & 9.38 & 0.18 & 6.01 & 5.99 & 8.52 & 16.80 & 9.93 & 6.49 & 13.73 \\
Dev. & & & & & & & & & & &
\end{tabular}

\begin{tabular}{llcccccccccccccc}
\hline $\mathbf{n}$ & 37 & 24 & 26 & 37 & 39 & 6 & 40 & 26 & 37 & 38 & 38 & 34 & 38 \\
& Mean & 423.89 & 5.90 & 10.60 & 6.81 & 11.52 & 0.82 & 12.14 & 9.07 & 11.04 & 37.68 & 7.40 & 5.92 & 18.22 \\
& Std & 245.74 & 3.89 & 1.44 & 0.75 & 15.48 & 1.63 & 6.77 & 8.30 & 12.87 & 27.10 & 5.21 & 7.63 & 9.23 \\
& Dev. & & & & & & & & & & &
\end{tabular}

\begin{tabular}{llccccccccccccc}
\hline $\mathbf{5}$ & $\mathbf{n}$ & 54 & 25 & 39 & 54 & 54 & 17 & 55 & 53 & 52 & 53 & 52 & 43 & 53 \\
& Mean & 582.96 & 5.69 & 11.50 & 7.09 & 12.37 & 0.10 & 11.81 & 9.35 & 6.76 & 55.64 & 4.51 & 4.08 & 15.79 \\
& Std & 133.64 & 3.14 & 0.82 & 0.43 & 31.16 & 0.11 & 6.02 & 5.52 & 4.49 & 21.89 & 4.25 & 3.21 & 8.82 \\
& Dev. & & & & & & & & & &
\end{tabular}

\begin{tabular}{rlccccccccccccc}
\hline Kruskal & $\mathbf{H}$ & 48.54 & 11.36 & 22.37 & 30.49 & 53.51 & $\mathrm{~N} / \mathrm{A}$ & 14.25 & 38.66 & 18.56 & 44.73 & 36.24 & 5.51 & 13.44 \\
Wallis & $\mathbf{D f}$ & 4 & 4 & 4 & 4 & 4 & & 4 & 4 & 4 & 4 & 4 & 4 & 4 \\
Test & $\boldsymbol{p}$ & $<0.001$ & $<0.001$ & $<0.001$ & $<0.001$ & $<0.001$ & & $<0.01$ & $<0.001$ & $<0.01$ & $<0.001$ & $<0.001$ & 0.239 & $<0.01$
\end{tabular}

$732 \quad$ N/A - insufficient data (majority of values below detection limit). 
735 Table 3: Abundance and composition of groundwater taxa (stygobionts and

736 stygophiles) in boreholes $(\mathrm{BH})$, wells and springs from the five hydro-units.

737

Attributes of sample sites

Sites sampled (no.)

\begin{tabular}{lllll} 
& Total & BHs & Wells & Springs \\
\hline No. of sites sampled: & 221 & 124 & 56 & 41 \\
No. of sites in each hydro-unit (Hu) & & & & \\
Granular (Hu1) & 10 & 9 & 1 & 0 \\
Igneous/metamorphic (Hu2) & 37 & 12 & 12 & 13 \\
Mudstone/siltstone (Hu3) & 56 & 28 & 19 & 9 \\
Sandstone (Hu4) & 55 & 34 & 11 & 10 \\
Carbonate (Hu5) & 63 & 41 & 13 & 9 \\
No. of sites with GW fauna & 155 & 70 & 51 & 34 \\
Sites with no GW fauna ${ }^{1}$ & 66 & 54 & 5 & 7 \\
No. of sites with stygobionts & 75 & 34 & 23 & 18
\end{tabular}

\begin{tabular}{lcccccc}
\hline Taxa groups \& species & $\begin{array}{l}\text { Total } \\
\text { Abundance }\end{array}$ & \multicolumn{2}{l}{$\begin{array}{l}\text { Percentage occurrence from all sites } \\
\text { Hydro-units }\end{array}$} \\
\hline Stygobionts & 465 & 33.8 & 27.4 & 40.4 & 43.9 & All \\
present
\end{tabular}

Crustacea, Malacostraca, Eumalacostraca

\section{Peracarida}

Amphipoda,

Niphargidae

$\begin{array}{lllllll}\text { Niphargus kochianus } & 181 & 10.8 & 12.9 & 12.3 & 2.5 & 3,5 \\ \text { Niphargus fontanus } & 28 & 5.4 & 4.8 & 7.0 & 4.9 & 1,5 \\ \text { Niphargus aquilex } & 96 & 10.4 & 8.1 & 12.3 & 14.6 & 1,2,3,4,5 \\ \text { Niphargus glenniei } & 79 & 8.6 & 2.4 & 12.3 & 22.0 & 2,3,4,5 \\ \text { Microniphargus leruthi } & 10 & 2.7 & 2.4 & 3.5 & 2.5 & 3,4,5 \\ \text { Crangonycitidae } & & & & & & 4,5 \\ \text { Crangonyx subterraneus } & 60 & 5.9 & 6.5 & 3.5 & 7.3 & 4,5\end{array}$

Isopoda

Asellidae

Proasellus cavaticus

10

2.3

$4.0 \quad 0$

0

5

Syncarida

Bathynellacea,

Bathynellidae 


$\begin{array}{lllllll}\text { Antrobathynella stammeri } & 1 & 0.5 & 0.8 & 0 & 0 & 4 \\ \text { Stygophiles } & 5318 & 63.5 & 44.4 & 86.0 & 90.2 & \text { All }\end{array}$

Crustacea, Maxillopoda

$\begin{array}{lllllll}\text { Copepoda } & 4181 & 47.3 & 26.6 & 70.2 & 78.0 & 1,2,3,4,5 \\ \text { Crustacea, Ostracoda } & 745 & 23.4 & 8.1 & 38.6 & 48.8 & 1,2,3,4,5\end{array}$

Arthropoda, Arachnida, Acari, Trombidiformes

Hydrachnidae

182

210

10.4

12.9

12.3

$2,3,4,5$

738

${ }^{* 1}$ Other freshwater (epigean) or terrestrial taxa may have been recorded at these sites

739

$*^{2}$ Not included where recovered from spring sources, due to presence of epigean species 
741 Table 4: Summary of odds ratios from generalized linear models selected to describe

742 relationships between presence/absence data, hydro-units $\mathrm{(Hu}$ and water chemistry.

743 (The level of significance reported in each model is represented by: ${ }^{*} 0.05,{ }^{* \star} 0.01$, $744 * \star * 0.001)$.

Odds ratios calculated relative to: 


\begin{tabular}{|c|c|c|c|c|c|c|c|}
\hline $\begin{array}{l}\text { Generalized linear model } \\
\text { (simplest model selected } \\
\text { based on comparison of all } \\
\text { model permutations) }\end{array}$ & $\begin{array}{l}\text { Determinand } \\
\text { (value) }\end{array}$ & 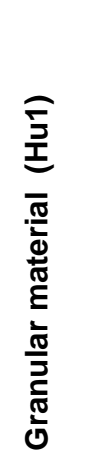 & 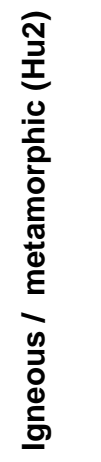 & 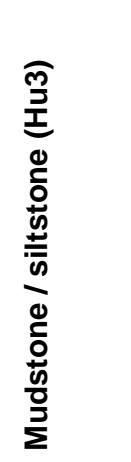 & 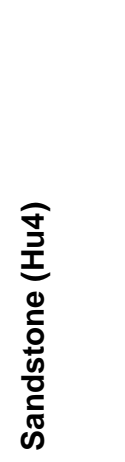 & 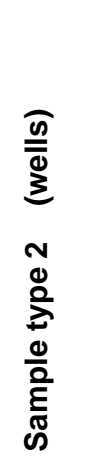 & 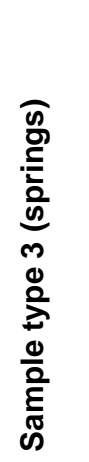 \\
\hline \multirow{4}{*}{$\begin{array}{l}\text { Pres/Abs Hydro-unit } \\
\chi^{2}=33.8, \mathrm{df}=5, p<0.001\end{array}$} & all data & 0.84 & 0.80 & $0.12^{\star \star \star}$ & $0.21^{\star \star \star}$ & & \\
\hline & dissolved oxygen & 2.00 & 1.00 & $0.16^{\star \star}$ & $0.26^{*}$ & & \\
\hline & nitrate & $\mathrm{N} / \mathrm{A}$ & 0.67 & $0.12^{\star \star \star}$ & $0.28 *$ & & \\
\hline & temperature & 2.38 & 1.48 & $0.15^{\star \star}$ & $0.23^{*}$ & & \\
\hline \multirow[t]{3}{*}{ Pres/Abs Hydro-unit + value } & calcium & 0.97 & 0.98 & $0.18^{\star *}$ & $0.27^{\star \star}$ & & \\
\hline & chloride & 0.93 & 0.63 & $0.11^{\star \star}$ & $0.20 * \star$ & & \\
\hline & $\mathrm{pH}$ & 0.96 & 0.56 & $0.08^{\star \star \star}$ & $0.16^{\star \star \star}$ & & \\
\hline \multirow[t]{6}{*}{ Pres/Abs Hydro-unit + sample type } & $\begin{array}{l}\text { Dissolved organic } \\
\text { carbon }\end{array}$ & 1.12 & 0.65 & $0.10^{\star * \star}$ & $0.21^{\star \star *}$ & $2.34^{*}$ & $3.01^{*}$ \\
\hline & elec. conductivity & 1.09 & 0.59 & $0.10^{\star \star \star}$ & $0.22^{* *}$ & 2.19 & 3.07 * \\
\hline & magnesium & 0.94 & 0.43 & $0.10^{* *}$ & $0.19^{\star \star *}$ & 1.83 & $3.22^{*}$ \\
\hline & potassium & 0.91 & $0.30 *$ & $0.07^{\star \star \star *}$ & $0.14^{\star \star *}$ & 1.77 & $4.52^{*}$ \\
\hline & sodium & 1.00 & 0.49 & $0.12^{\star \star \star}$ & $0.21^{\star *}$ & 1.92 & $3.20^{*}$ \\
\hline & sulphate & 1.89 & 0.49 & $0.09 * \star \star$ & $0.19 * *$ & 1.86 & $3.51 *$ \\
\hline
\end{tabular}

$746 \quad$ N/A - excluded from analysis because insufficient reliable nitrate data available

747 Level of significance in model ${ }^{*} 0.05,{ }^{* \star} 0.01,{ }^{* \star *} 0.001$

748

749

750

751

752

753

754 
756 Table 5: Partialled CCA results showing percentage of variation in species data explained

757 by environmental variables; hydro-units \& groundwater chemistry, together and in isolation.

758

$\begin{array}{clllll}\text { CCA } & \begin{array}{l}\text { Constraint on } \\ \text { Species data }\end{array} & \begin{array}{l}\text { Variable } \\ \text { partialled out } \\ \text { (covariable) }\end{array} & \begin{array}{l}\text { Sum of all } \\ \text { canonical } \\ \text { eigen-values } \\ \text { (Ev) }\end{array} & \begin{array}{l}\text { Percentage } \\ \text { variation } \\ \text { (Ev } x\end{array} & \begin{array}{l}\text { Fraction of variation } \\ \text { explained by }\end{array} \\ & & & \text { 100/4.998) } & \end{array}$

\begin{tabular}{lllllc}
\hline CCA1 & Chemistry & none & 0.429 & $8.58 \%$ & - \\
CCA2 & Hydro-units & none & 0.628 & $12.57 \%$ & - \\
CCA3 & Hydro-units & Chemistry & 0.251 & $5.02 \%$ & Chemistry \\
CCA4 & Chemistry & Hydro-units & 0.376 & $7.52 \%$ & Hydro-units
\end{tabular}

Sum of all eigenvalues in a species only CA $\quad 4.998$

Overall amount of variation due to environmental variables

$16.11 \%$

CCA1 + CC4

Variation due to hydro-units \& water chemistry together

$3.56 \%$

CCA1 - CCA3

Variation unexplained by hydro-units \&/or water chemistry

$83.89 \%$

$100-(\mathrm{CCA} 1+\mathrm{CCA} 4)$ 